\title{
Isolation and Characterization of Outer Membrane Vesicles of Pectobacterium brasiliense 1692
}

\author{
Silindile Maphosa ${ }^{1,2}$ and Lucy Novungayo Moleleki ${ }^{1,2, *}$ \\ 1 Department of Biochemistry, Genetics and Microbiology, University of Pretoria, Lunnon Road, \\ Pretoria 0028, South Africa; silindile.maphosa@up.ac.za \\ 2 Forestry and Agricultural Biotechnology Institute (FABI), University of Pretoria, Lunnon Road, \\ Pretoria 0028, South Africa \\ * Correspondence: lucy.moleleki@up.ac.za; Tel.: +27-(0)12-4204662
}

check for updates

Citation: Maphosa, S.; Moleleki, L.N. Isolation and Characterization of Outer Membrane Vesicles of Pectobacterium brasiliense 1692. Microorganisms 2021, 9, 1918. https://doi.org/10.3390/ microorganisms 9091918

Academic Editor: Denis Faure

Received: 16 August 2021

Accepted: 3 September 2021

Published: 9 September 2021

Publisher's Note: MDPI stays neutral with regard to jurisdictional claims in published maps and institutional affiliations.

Copyright: (c) 2021 by the authors. Licensee MDPI, Basel, Switzerland. This article is an open access article distributed under the terms and conditions of the Creative Commons Attribution (CC BY) license (https:/ / creativecommons.org/licenses/by/ $4.0 /)$.

\begin{abstract}
Pectobacterium brasiliense (Pbr) 1692 is an aggressive phytopathogen affecting a broad host range of crops and ornamental plants, including potatoes. Previous research on animal pathogens, and a few plant pathogens, revealed that Outer Membrane Vesicles (OMVs) are part of Gram-negative bacteria's (GNB) adaptive toolkit. For this reason, OMV production and subsequent release from bacteria is a conserved process. Therefore, we hypothesized that OMVs might transport proteins that play a critical role in causing soft rot disease and in the survival and fitness of Pbr1692. Here, we show that the potato pathogen, Pbr1692, releases OMVs of various morphologies in Luria Bertani media at $31^{\circ} \mathrm{C}$. Scanning Electron Microscopy (SEM) and Transmission Electron Microscopy (TEM) confirmed the production of OMVs by Pbr1692 cells. Transmission Electron Microscopy showed that these exist as chain-, single-, and double-membrane morphologies. Mass spectrometry followed by Gene Ontology, Clusters of Orthologous Groups, Virulence Factor, CAZymes, Antibiotic Resistance Ontology, and Bastion6 T6SE annotations identified 129 OMV-associated proteins with diverse annotated roles, including antibiotic stress response, virulence, and competition. Pbr1692 OMVs contributed to virulence in potato tubers and elicited a hypersensitive response in Nicotiana benthamiana leaves. Furthermore, Pbr1692 OMVs demonstrated antibacterial activity against Dickeya dadantii.
\end{abstract}

Keywords: outer membrane vesicles (OMVs); Pectobacterium brasiliense 1692; virulence; competition

\section{Introduction}

Soft Rot Pectobacteriaceae (SRP) are Gram-negative bacteria (GNB) responsible for annual crop losses amounting to millions of dollars worldwide [1]. Dickeya and Pectobacterium spp. are the primary soft rot pathogens causing wilting, blackleg, and tuber decay of potatoes (Solanum tuberosum L.), other vegetables, and ornamental plants [2,3]. First reported in Brazil, Pbr is not only found in different parts of the world but has also become a significant threat to the production of economically important crops globally [4-6]. Pbr, like other soft rot bacteria, exhibits many determinants that ensure their persistence in the environment and expansion into new territory and hosts. Similar to other SRP, the main virulence determinants are consignments of plant-cell-wall-degrading enzymes (PCWDEs), such as pectinases, cellulases, and proteinases, which make the genus effective in macerating plant tissue [1]. Apart from PCWDEs secreted via the Type 2 Secretion System (T2SS), SRP have an arsenal of virulence factors that elevate pathogenesis. These include iron acquisition, quorum sensing, fimbriae, flagella and motility, polysaccharides, and bacterial secretion systems (T1-, T3-, T4-, T5-, and T6SS), with outer membrane vesicles (OMVs) considered a bacterial Type 0 secretion system [1,7-11]. Indeed, the role of secretion systems in the coordinated interaction of bacteria with their environment, target hosts, and other bacteria is pivotal [12]. These systems release many proteinaceous and chemical substances for virulence and persistence from the cell cytosol to the extracellular milieu, neighboring cells, 
and host cells. Extensive studies of T1SS-T6SSs have determined their composition and the substances they deliver [13].

In general, Membrane Vesicles (MVs) form in GNB by pinching off the outer membranes (OMs), resulting in OMVs and Gram-Positive Bacteria (GPB) by disrupting the peptidoglycan layer forming microvesicles [14]. Owing to their essential role in transferring bioactive molecules from donor to recipient cells, MVs, particularly OMVs in GNB, are ubiquitous and conserved [7,10,11]. Although models of the mechanisms of biogenesis, cargo, and functions of OMVs continue to be reported, not much is known about the mechanism of loading and sorting of the cargo into the vesicles for transportation $[15,16]$. Outer membrane-derived OMVs are enriched in periplasmic proteins, while outer-inner membrane vesicles (OIMVs) have inner and outer membranes enriched in addition to periplasmic proteins and cytoplasmic contents. More so, Explosive OMVs (EOMVs) carrying cytoplasmic proteins in addition to periplasmic proteins have been reported [16-18]. Studies also report OMVs of larger sizes, aggregates, chains, and tubes [19]. However, there are no baselines for isolation methods; hence, the types, cargo, and specific functions of OMVs will vary from one species to another, making comparisons difficult $[20,21]$. We have yet to learn more about the species and strain-specific roles of OMVs of phytopathogenic bacteria in bacteria-bacteria and bacteria-host interactions, as well as their potential to control plant diseases.

So far, we know that OMVs have physiological, protective, and adaptative roles in the environment, as reviewed in [22,23]. Phytopathogenic bacteria produce OMVs involved in colonization, virulence, host immune elicitation or evasion, defense neutralization, and biofilm formation [24-26]. Therefore, bacterial cells communicate with each other and the environment through OMVs. This form of communication is without energy expenditure to transfer bacterial messenger molecules, toxins, and nutrient acquisition/scavenging systems that consequently affect the environment even though cargo sorting into and producing OMVs is likely resource depleting [14,15]. Moreover, the rapid release of toxins and misfolded proteins produced under stressful conditions, surface binding and antimicrobial agents, and hydrolytic enzymes ensures the survival of the producing bacteria [19]. Unlike other secretion mechanisms that solely transport soluble material, OMVs enable bacteria to secrete insoluble molecules complexed with soluble material [27]. Since they transport a set of biological macromolecules typifying most secretion systems' substrate, OMVs play a critical role as the GNB secretion systems' succor system. Therefore, bacterial OMVs provide relief from the secretion burden to delivery systems [7]. OMVs ferry lipopolysaccharides (LPS), phospholipids, peptidoglycan, Outer Membrane Proteins (OMPs), cytoplasmic proteins, nucleic acids, ion metabolites, and signaling molecules as part of their structure and in their lumen for various destination outcomes [28,29]. External surface association of toxins and nucleic acids with OMVs also exists [30]. Upon reaching the targeted destination, OMVs release their cargo, which may be involved in different biological roles [22,31]. Exploration of OMV cargo in other GNB points to several such roles, including increased virulence, immune activation or suppression, biofilm formation, inter- or intraspecies and interkingdom delivery of defensive and offensive molecules, respectively, uptake, and pathogen adherence or detachment [24,32-34]. For example, Enterotoxigenic Escherichia coli (ETEC) vesicles are essential in disseminating heat-labile enterotoxin to host cells during bacterial infection leading to diarrhoea [35]. The OMV-enriched proteome of two human microbiota, Bacteroides fragilis and Bacteroides thetaiotaomicron showed high glycosidases and proteases, including those active in vitro [36]. Moreover, proteomics has identified different putative biologically active molecules like nucleotides and immunogenic peptidoglycan [37]. OMV proteins are involved in communication, nutrient acquisition, stress responses, and virulence [23]. Some of the identified OMV-specific proteins in previous studies are uncharacterized hypothetical proteins; hence, it may be challenging to predict functions for these or fully understand the proteins found in the vesicles [38].

Pbr1692 is more virulent than other Pectobacterium spp. and is able to outcompete other members of SRP under different environmental conditions $[39,40]$. We presupposed 
that OMVs could contribute to the delivery of PCWDEs, toxins, and effectors involved in either virulence or competition. In this work, we established that Pbr1692 naturally releases MVs throughout its growth. These OMVs could macerate potato tuber tissue, elicit a hypersensitive response (HR) on Nicotiana benthamiana leaves, and were able to inhibit the growth of another SRP, D. dadantii. We carried out proteomics analysis of isolated vesicles to identify the OMV-associated proteins. Functional annotations showed that diverse functions could be ascribed to Pbr1692 OMVs centralized in virulence and fitness.

\section{Materials and Methods}

\subsection{The Strains and Growth Conditions}

Pbr1692 and D. dadantii (with plasmid pMP7605 conferring gentamycin resistance) were cultured in Luria Bertani (LB) media at 31 and $32{ }^{\circ} \mathrm{C}$, respectively, with shaking at $120 \mathrm{rpm}$ for $12-14 \mathrm{~h}$. Where required, for the growth of $D$. dadantii, growth media were supplemented with $15 \mu \mathrm{g} / \mathrm{mL}$ gentamycin antibiotic (Sigma-Aldrich, St. Louis, MO, USA).

\subsection{Scanning Electron Microscopy Analysis of Cells}

Five milliliters of Pbr1692 cells in exponential and stationary phase were pelleted at $3000 \mathrm{rpm}$ for $3 \mathrm{~min}$. The supernatant was discarded, and then cell pellets were washed with $0.1 \mathrm{M}$ phosphate buffer $\mathrm{pH} 7.4$ on a rotator and after the fixation and post-fixation steps thrice for $10 \mathrm{~min}$. First, the cells were resuspended in $2.5 \%$ glutaraldehyde fixative for $30 \mathrm{~min}$, post-fixed with $1 \%$ osmium tetroxide $(w / v)$ for $30 \mathrm{~min}$, and then dehydrated by a graded series of ethanol (30\%, 50\%, 70\%, and 90\%) for $10 \mathrm{~min}$. The cells were then dehydrated by $100 \%$ ethanol twice for $10 \mathrm{~min}$ and once for $40 \mathrm{~min}$. Next, the cells were pelleted and embedded in hexamethyldisilazane (HMDS): ethanol mixture for $1 \mathrm{~h}$ twice. Following this, fresh HDMS was added, and then the cells were left to dry. The cells were then mounted and coated with carbon for visualization using the Zeiss Crossbeam 540 Field Emission-Scanning Electron Microscope (FE-SEM) (Zeiss, Oberkochen, Germany) operated at $1.00 \mathrm{kV}$.

\subsection{Transmission Electron Microscopy Analysis of Cells}

Five milliliters of Pbr1692 culture in the stationary phase were pelleted at $3000 \mathrm{rpm}$ for $3 \mathrm{~min}$. The supernatant was discarded, and then the cell pellet was washed with phosphate buffer on a rotator and after the fixation and post-fixation steps thrice for 10 min each time. The cells were resuspended in $2.5 \%$ glutaraldehyde fixative for $30 \mathrm{~min}$ and then post-fixed with $1 \%$ osmium tetroxide $(w / v)$ for $30 \mathrm{~min}$. After that, a graded series of ethanol $(30 \%$, $50 \%, 70 \%$, and $90 \%$ ) was used to dehydrate the cells for $10 \mathrm{~min}$. Dehydration by $100 \%$ ethanol was done twice for $10 \mathrm{~min}$ and once for $40 \mathrm{~min}$. Dehydrated cells were mixed with epoxy resin:ethanol mixture for $1 \mathrm{~h}$ twice. Fresh epoxy was added, and then the cells were dried in an oven for over $24 \mathrm{~h}$ for polymerization. The embedded sample was trimmed, sectioned, and stained for visualization using the transmission electron microscope (TEM) (JOEL JEM 2100F, JOEL Ltd., Tokyo, Japan).

\subsection{Isolation of $\mathrm{OMVS}$}

OMVs were isolated at the stationary growth phase of Pbr1692 (OD 600 of $1-1.2$ ) according to $[41,42]$ with modifications. First, the Pbr1692 culture was subjected to lowspeed centrifugation at $16,000 \times g$ for $20 \mathrm{~min}$ at $4{ }^{\circ} \mathrm{C}$ to pellet the cells. After that, cell debris and macromolecules were removed by high-speed centrifugation at $38,000 \times g$ for $1 \mathrm{~h}$ at $4{ }^{\circ} \mathrm{C}$. The cell-free supernatant was filtered using a $0.22 \mu \mathrm{m}$ bottle filter top under vacuum to remove residual cells (Merck, Darmstadt, Germany). LB agar plates were inoculated with $200 \mu \mathrm{L}$ of cell-free filtrates and incubated at $31^{\circ} \mathrm{C}$ for $48 \mathrm{~h}$ to ensure total removal of bacterial cells. The cell-free supernatants were reduced 100 -fold by concentration in Amicon ${ }^{\circledR}$ Ultra-15 (MWCO 30 kDa) centrifugal units (Merck, Darmstadt, Germany). OMVs were pelleted from the concentrated supernatant in an SW 55 Ti Rotor (Beckman Coulter, Brea, CA, USA) at $145,000 \times g$ at $4{ }^{\circ} \mathrm{C}$ for $6 \mathrm{~h}$ and then resuspended in phosphate-buffered 
saline (PBS) (Sigma-Aldrich, St. Louis, MO, USA). OMVs for virulence assays were washed twice in the SW $55 \mathrm{Ti}$ Rotor at $145,000 \times g$ at $4{ }^{\circ} \mathrm{C}$ for $6 \mathrm{~h}$. Protein concentration was checked using the nanodrop at $\mathrm{A}_{280}$. OMV samples were stored at -20 or $-80^{\circ} \mathrm{C}$ after freezing in liquid nitrogen.

\subsection{Negative Staining of OMVs}

Purified OMVs were spotted on carbon-coated grids for adsorption for $5 \mathrm{~min}$. The vesicles were, after that, negatively stained with $1 \%(w / v)$ uranyl acetate for 3 min. Finally, the OMVs were visualized using TEM (JOEL JEM 2100F, JOEL Ltd., Tokyo, Japan).

\subsection{Nanoparticle Tracking Analysis and Bradford Assay of Cell-Free Supernatants}

Isolated OMV samples and Pbr1692 cell-free supernatants were analyzed using the NanoSight NTA v3.3 (Malvern Panalytical, Malvern, UK) to determine nanoparticle concentration and distribution. Cell-free supernatants were prepared for NTA according to [25] with slight modifications. Three biological replicates of Pbr1692 cells were grown to the exponential $\left(\mathrm{OD}_{600}\right.$ of $\sim 0.5$ ) and stationary growth phase $\left(\mathrm{OD}_{600}\right.$ of $\left.\sim 1.0\right)$. Cells were pelleted out of culture using low-speed centrifugation at $16,000 \times g$ for 20 min twice at $4{ }^{\circ} \mathrm{C}$. The cell-free supernatants were filtered under vacuum to remove residual bacterial cells. A test volume of $1.5 \mathrm{~mL}$ of each replicate was injected into the NTA and analyzed in triplicate (each run $=30 \mathrm{~s}$ video). The videos were captured and processed using NTA 3.3 Dev Build 3.3.104 (Malvern, Panalytical, Malvern, UK). In between runs, samples were advanced to introduce fresh sample aliquots for quantification. The camera sensitivity and detection threshold were optimized per video, and the temperature was set between 20 and $22{ }^{\circ} \mathrm{C}$. Readings were analyzed using the NTA software version 3.3. LB media were used as a blank. The Bradford reagent was used to determine the protein concentration of the cell-free supernatants (Bio-Rad Laboratories, Hercules, CA, USA ) using bovine serum albumin (BSA) as a standard (Sigma-Aldrich, St. Louis, MO, USA).

\subsection{Protein Extraction and Digestion}

OMV proteins of three biological replicates were extracted according to the BGI Tech Solutions Co., Ltd. (Hong Kong, China) protocol. The OMVs were mixed with $1 \mathrm{~mL}$ PBS and centrifuged at $1000 \times g$ at $4{ }^{\circ} \mathrm{C}$ twice for $1 \mathrm{~min}$. Each time, the supernatant was discarded. Two steel beads, a 1X cocktail with appropriate amounts of SDS L3 and EDTA were added, and then the tube was incubated on ice for $5 \mathrm{~min}$. After incubation, $10 \mathrm{mM}$ dithiothreitol (DTT) was added. The mixture was placed on a grinder at $60 \mathrm{~Hz}$ frequency for $2 \mathrm{~min}$ to crush the tissue and then centrifuged at $25,000 \times \mathrm{g}$ at $4{ }^{\circ} \mathrm{C}$ for $15 \mathrm{~min}$. The supernatant was transferred into a fresh tube, and $10 \mathrm{mM}$ DTT was added before incubation in a water bath at $56{ }^{\circ} \mathrm{C}$ for $1 \mathrm{~h}$. Next, iodoacetamide (IAM) at a final concentration of $55 \mathrm{Mm}$ was added, and then the samples were placed in a dark room for $45 \mathrm{~min}$. Next, cold acetone was added to the protein solution at a ratio of 1:5, and then the samples were refrigerated at $-20^{\circ} \mathrm{C}$ for $30 \mathrm{~min}$. After freezing, the samples were centrifuged at $25,000 \times g$ at $4{ }^{\circ} \mathrm{C}$ for $15 \mathrm{~min}$, and then the supernatant was discarded. The protein was precipitated by air-drying before the addition of lysis buffer without SDS L3. The grinder at $60 \mathrm{~Hz}$ (2 min) was used to promote protein solubilization. Post solubilization, the samples were centrifuged for $15 \mathrm{~min}$ at $25,000 \times \mathrm{g}$ at $4{ }^{\circ} \mathrm{C}$ to recover the protein-containing supernatant.

Proteins were separated by SDS PAGE gel electrophoresis and extracted from the gel strips. The strips were decolorized in ammonium bicarbonate $\left(\mathrm{NH}_{4} \mathrm{HCO}_{3}\right)$ :acetonitrile $(\mathrm{ACN})$ mixture $(v / v)$ at $37^{\circ} \mathrm{C}$ for $30 \mathrm{~min}$, then centrifuged and dried. The gels were dehydrated using $500 \mu \mathrm{L}$ acetonitrile twice and then left to air dry. The gels were covered in $10 \mathrm{mM}$ DTT and incubated at $56^{\circ} \mathrm{C}$ for $1 \mathrm{~h}$. After that, the gel was soaked with $55 \mathrm{mM}$ IAM and kept in the darkroom at room temperature for $45 \mathrm{~min}$. The samples were washed with discolorizing solution and then with pure water before adding $500 \mu \mathrm{L}$ acetonitrile. The samples were vortexed for $5 \mathrm{~min}$ and, after the addition of acetonitrile, were left to dry thoroughly. The dry gel samples were digested by covering them in enzyme solution 
diluted to $0.01 \mu \mathrm{g} / \mu \mathrm{L}$ with $25 \mathrm{mM} \mathrm{NH}_{4} \mathrm{HCO}_{3}$ for $30 \mathrm{~min}$ at $4{ }^{\circ} \mathrm{C}$ and then incubating in buffer overnight at $37^{\circ} \mathrm{C}$. Fifty percent and $100 \%$ acetonitrile were added in series before centrifugation at $5000 \times g$ each time before the samples were freeze-dried.

\subsection{High-Performance Liquid Chromatography (HPLC)}

The freeze-dried peptide samples were reconstituted with mobile phase A ( $2 \% \mathrm{ACN}$, $0.1 \% \mathrm{FA}$ ), centrifuged at $20,000 \times g$ for $10 \mathrm{~min}$. The supernatant was taken for injection and separated by a Shimadzu LC-20AD model nanoliter liquid chromatograph. The sample was first enriched in the trap column and desalted and then channeled into a tandem self-packed C18 column (75 $\mu \mathrm{m}$ internal diameter, $3 \mu \mathrm{m}$ column size, $15 \mathrm{~cm}$ column length). Separation was at a flow rate of $300 \mathrm{~nL} / \mathrm{min}$ by the following effective gradient: 0-6 min, $6 \%$ mobile phase B ( $98 \%$ ACN, $0.1 \%$ FA); $6-40$ min, mobile phase B linearly increased from $6 \%$ to $25 \%$; $40-48 \mathrm{~min}$, mobile phase B rose from $25 \%$ to $40 \% ; 48-51 \mathrm{~min}$, mobile phase $\mathrm{B}$ rose from $40 \%$ to $90 \%$; $51-55 \mathrm{~min}, 90 \%$ mobile phase B; $55.5-60 \mathrm{~min}, 6 \%$ mobile phase $\mathrm{B}$. The nanoliter liquid phase separation end was directly connected to the mass spectrometer.

\subsection{Electrospray Ionization Mass Spectrometry (ESI-MS/MS)}

Liquid phase chromatography-separated peptides were passed to the ESI tandem mass spectrophotometer, TripleTOF 5600 (SCIEX, Framingham, MA, USA). Nanospray was used as an ion source (SCIEX, Framingham, MA, USA), and the emitter was a needle (New Objectives, Woburn, MA, USA) drawn from quartz material. The specific applied parameters of ion spray voltage $2300 \mathrm{~V}$, nitrogen pressure 35 psi, spray gas 15 , and spray interface temperature $150^{\circ} \mathrm{C}$ were set. Scanning in high sensitivity mode, the cumulative scan time was $250 \mathrm{~ms}$, and the scan quality range was between 350 and $1500 \mathrm{Da}$. Based on the MSI scanning information and the ionic strength in the MSI spectrum from high to low, the first 30 ions that exceeded $150 \mathrm{cp}$ were fragmented, and the MS2 information was scanned. The screening was done according to the following criteria: (a) the $m / z$ range was 350-1250 $\mathrm{m} / \mathrm{z}$; (b) the number of charges was 2-5 charges; (c) the dynamic elimination of the parent ion was set to half of the peak time ( 12 s); and the fragmentation of the same parent ion did not exceed 2 times. The scan accumulation time MS2 mass spectrum was $50 \mathrm{~ms}$. The collision energy was set to 'Rolling Collision Energy'.

\subsection{Database Search and Quantification}

The MS/MS experimental data were aligned with theoretical MS/MS data from a Pbr database (14,096 sequences). First, the MS/MS raw data were converted to an *mgf file and searched for matches in the database using Mascot software (Matrix Science, London, UK; version 2.3.02). A fragment mass tolerance of 0.1 Da and a peptide tolerance of $0.05 \mathrm{Da}$ were set. Carbamidomethylation cysteine (C) was the fixed modification. The oxidation of methionine (M), conversion of $\mathrm{N}$-terminal glutamine (Gln) to pyroglutamic acid (pyro-Glu), and the deamination of $\mathrm{N}$-terminal glutamine $(\mathrm{Q})$ were set as variable modifications. Trypsin specificity was set to allow 1 missed cleavage. The search results were rescored using Percolator to improve the matching accuracy. Then, the output was filtered by a $1 \%$ false determination rate (FDR) at the spectral level (PSM-level FDR $\leq 0.01$ ) to obtain the significant identified spectrum and peptide list. Proteins were linked to peptides, and a series of protein groups were generated. The intensity-based absolute protein quantification (iBAQ) was carried out as previously described [43].

\subsection{Sequence Analysis and Annotations}

The protein sequences were first retrieved from the UniProt database to establish their functional annotations. The Gene Ontology (GO) term claims for the proteins were assigned using the GO international standard gene function classification system [44]. The GO functional annotation included protein2go and go2protein. The subcellular localization of each identified protein was predicted using PSORTb v3.0.3 [45]. Protein classification was carried out using the Clusters of Orthologous Groups of Proteins Sys- 
tem (COG) [46]. Virulence proteins were identified using the Virulence Factor DataBase (VFDB) [47]. Carbohydrate-Active enZYme (CAZyme) annotation was performed using dbCAN2 [48]. We also used a Comprehensive Antibiotic Resistance Database (CARD) to identify proteins essential for the persistence of Pbr1692 in the presence of antibiotics [49]. Type 6 secreted effectors (T6SE) were predicted using Bastion6 [50].

\subsection{Virulence Assays of Pbr1692 OMVs}

2.12.1. Protease Activity of OMVs

Twenty micrograms of OMVs was mixed with loading buffer (without $\beta$-mercaptoethanol) and incubated at room temperature for $10 \mathrm{~min}$. The samples were then loaded onto a $12 \%$ SDS- $0.1 \%$ gelatin-polyacrylamide gel $(v / v)$. The gel was run at $150 \mathrm{~V}(30-50 \mathrm{~mA})$ using a $1 \mathrm{X}$ electrophoresis buffer. Gelatinase activation was performed by washing the gel three times with gelatinase renaturation buffer for $20 \mathrm{~min}$ each time with agitation. After that, the gel was incubated in a washing buffer for $24 \mathrm{~h}$ at $37^{\circ} \mathrm{C}$. For staining, the gel was incubated in Coomassie Brilliant blue G 250 gel staining solution for $1 \mathrm{~h}$ at room temperature in a shaker. The gel was destained in the destaining solution until visible clearing was observed.

\subsubsection{Maceration of Potato Tubers}

Tap-water-washed Solanum tuberosum L. (cv. Mondial, a susceptible cultivar) potato tubers were surface sterilized by soaking in $10 \%(v / v)$ sodium hypochlorite $(\mathrm{NaOCl})$ for $10 \mathrm{~min}$. The potatoes were rinsed three times with sterile distilled water and then once with $96 \%$ ethanol. The potatoes were then allowed to air dry before $1 \mathrm{~cm}$ holes were punched with a sterile tip. The generated wounds were inoculated with $10 \mu \mathrm{L} \mathrm{OMV} \mathrm{suspension} \mathrm{in}$ PBS ( 1 $\times 10^{11}$ OMVs/mL), OD 600 of 1 Pbr1692 cells, and Pbr1692 cell-free supernatant. For the negative control, sterile PBS was inoculated. The inoculation sites were then sealed with petroleum jelly, and the potatoes were incubated under humid conditions at $31{ }^{\circ} \mathrm{C}$ for $72 \mathrm{~h}$. The lesion sizes were measured at this time. The experiment was carried out using three biological replicates, two independent times.

\subsubsection{Nicotiana benthamiana Elicitation of Hypersensitive Response by Pbr1692 OMVs}

Two two-week-old $N$. benthamiana plants were infiltrated by piercing three different leaves per plant with a needle and saturating each leaf with $1 \mathrm{mg} / \mathrm{mL}$ OMVs, cell-free supernatant, and OMV-wash supernatant as a control through the puncture two independent times.

\subsection{Antimicrobial Activity of OMVs}

Frozen stocks of target soft rot bacterium, D. dadantii (harboring pMP7605 which confers gentamycin resistance), and Pbr1692 were streaked on LB agar plates and incubated overnight at 32 and $31^{\circ} \mathrm{C}$, respectively. Single colonies were picked from the plates to inoculate $20 \mathrm{~mL}$ of fresh LB broth and incubated as above with shaking at $120 \mathrm{rpm}$ for 12-14 h. Overnight cultures were then normalized to $\mathrm{OD}_{600}$ of 0.5 . Twenty microliters of OMV suspension in PBS $\left(\sim 1 \times 10^{11} \mathrm{OMVs} / \mathrm{mL}\right)$ and $D$. dadantii $\left(\mathrm{OD}_{600}\right.$ of 0.5$)$ was mixed in a 1:1 ratio and spotted on an LB agar plate and then incubated at $32{ }^{\circ} \mathrm{C}$ for $16 \mathrm{~h}$. A volume of $20 \mu \mathrm{L}$ D. dadantii $\left(\mathrm{OD}_{600}\right.$ of 0.5$)$ cells was also mixed with an equal volume of the normalized Pbr1692 cells $\left(\mathrm{OD}_{600}\right.$ of 0.5$)$ as a positive control. PBS was used as a negative control. All the spots were scrapped into $1 \mathrm{~mL}$ LB post-incubation, serially diluted with sterile water, and then plated on LB plates supplemented with gentamycin. The single colonies were counted to enumerate viable cells in three independent plates.

\subsection{Statistical Analysis}

In this study, experiments were performed in triplicate two independent times. Where applicable, a student $\mathrm{t}$-test and analysis of variance using $\mathrm{R}$ version 3.6.1 were performed to determine statistical significance, and a $p$-value less than 0.05 or $0.01(p<0.05$ or $p<0.01)$ was a statistically significant difference. 


\section{Results}

\subsection{Identification of Pbr1692 OMVs}

To establish whether Pbr1692 produces OMVs in rich media, SEM was used to analyze cells cultured to exponential and stationary growth phases (Figure 1A-D). OMVs were observed budding off from or on the surfaces of rod-shaped bacterial cells both in the exponential and stationary phases. OMV aggregates and biofilm-like matrix structures were observed at both time points (Figure 1B,D). In addition, there were distinct areas on the bacterium where OMV clustering signaled where production was concentrated, "hot spots" (white arrows).
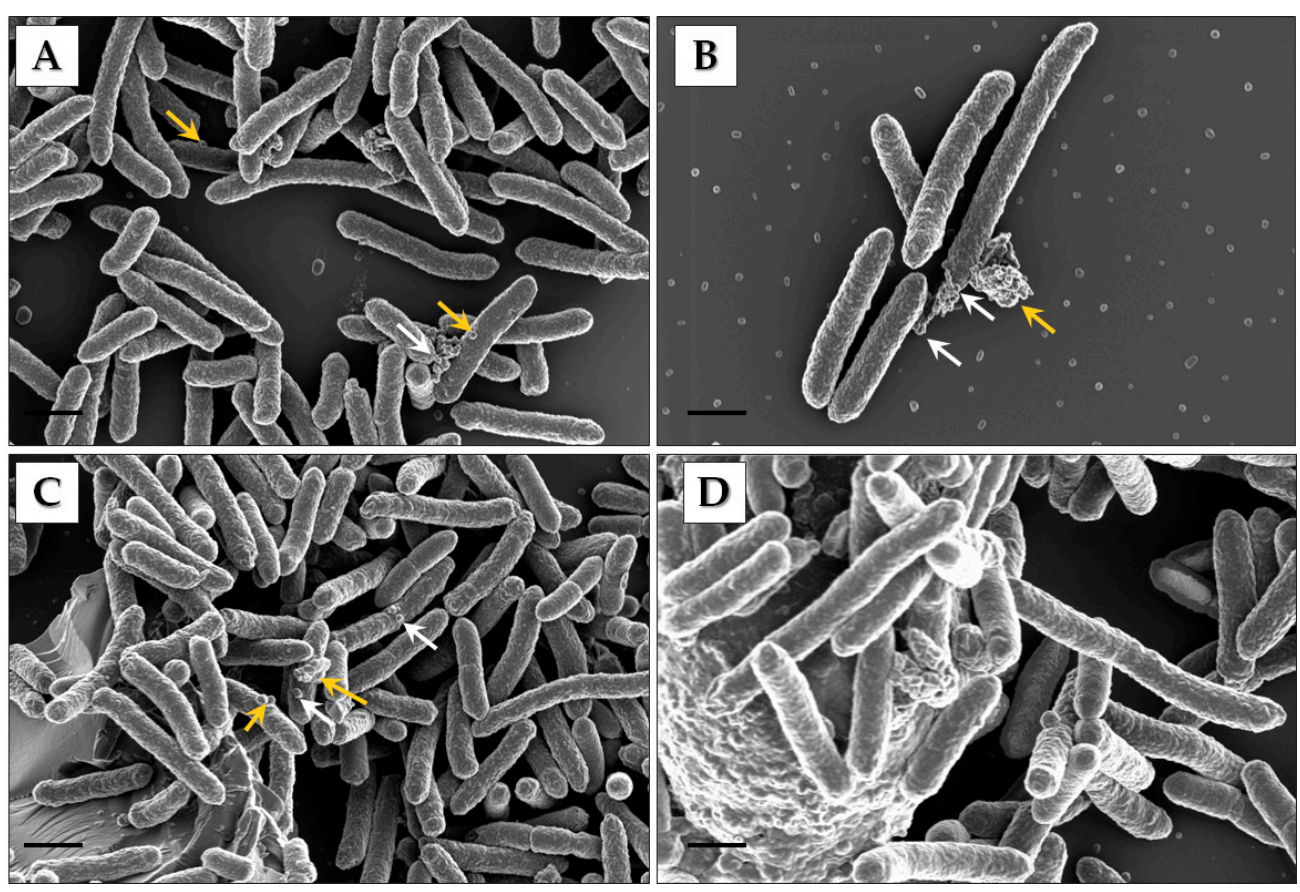

Figure 1. Identification of OMVs produced by Pbr1692. (A,B) In the SEM images, gold arrows indicate OMVs of cells and OMV aggregates in the exponential growth phase. The white arrows show vesiculation "hot spots". (C) The image of cells in stationary growth shows OMVs at the surface of the bacteria indicated by white arrows. Gold arrows indicate OMV aggregates and "hot spots". (D) The image shows OMVs embedded in the biofilm matrix-like backbone. Scale bars $=1 \mu \mathrm{m}$.

\subsection{Electron Microscopy and Nanoparticle Analysis of Vesicles}

Pbr1692-pelleted cells were analyzed using TEM to observe budding vesicles (Figure 2A). The cell density and total protein concentration of exponential and stationary cell-free supernatants were $\mathrm{OD}_{600}$ of 0.547 and 1.050 with a total protein of 60 and $102 \mu \mathrm{g} / \mathrm{mL}$, respectively. However, with no statistically significant difference in nanoparticle concentration or size distribution (Figure S1), OMVs were isolated in the stationary phase and analyzed using NTA. The OMV particle size distribution of $75-355 \mathrm{~nm}$ is shown in Figure 2B. The recorded average size was $173 \pm 1.9 \mathrm{~nm}$, and the mode diameter was $150.5 \pm 7.9 \mathrm{~nm}$.

The isolated OMVs were negatively stained and analyzed using TEM (Figure 3). Vesicles of different sizes and morphologies were observed. OMVs of varying sizes are shown (Figure 3A). Chain-like and aggregated OMVs were also identified (Figure 3B). Some of the vesicles had double membranes (Figure 3C). 

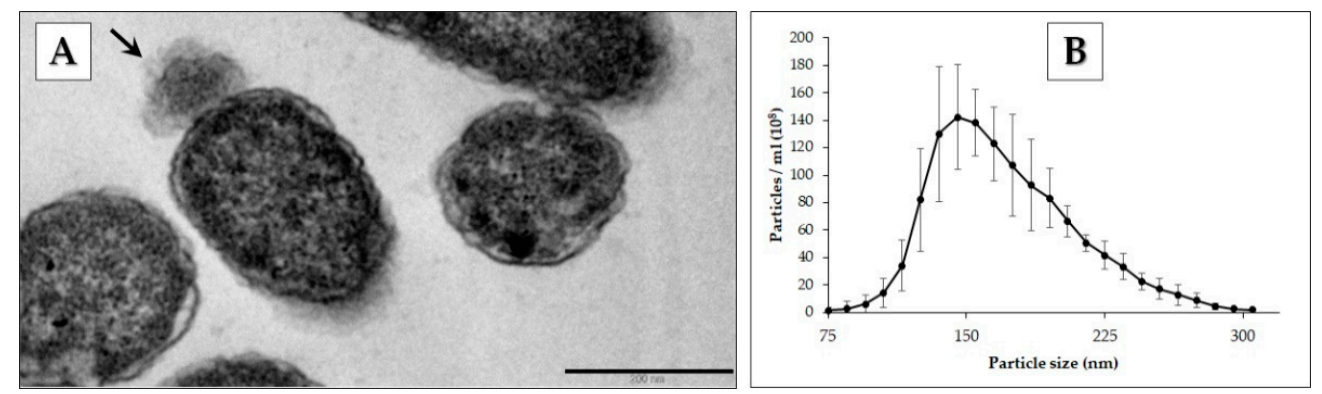

Figure 2. TEM identification of budding vesicles on Pbr1692 cells and isolated OMV size and distribution. (A) The arrow indicates an OMV budding from a Pbr1692 cell. Bar: $200 \mathrm{~nm}$. (B) NTA size distribution and quantification of isolated OMV assessment shows the distribution of Pbr1692 OMVs with an average size of $173.7 \pm 1.9 \mathrm{~nm}$ isolated in the stationary growth phase.
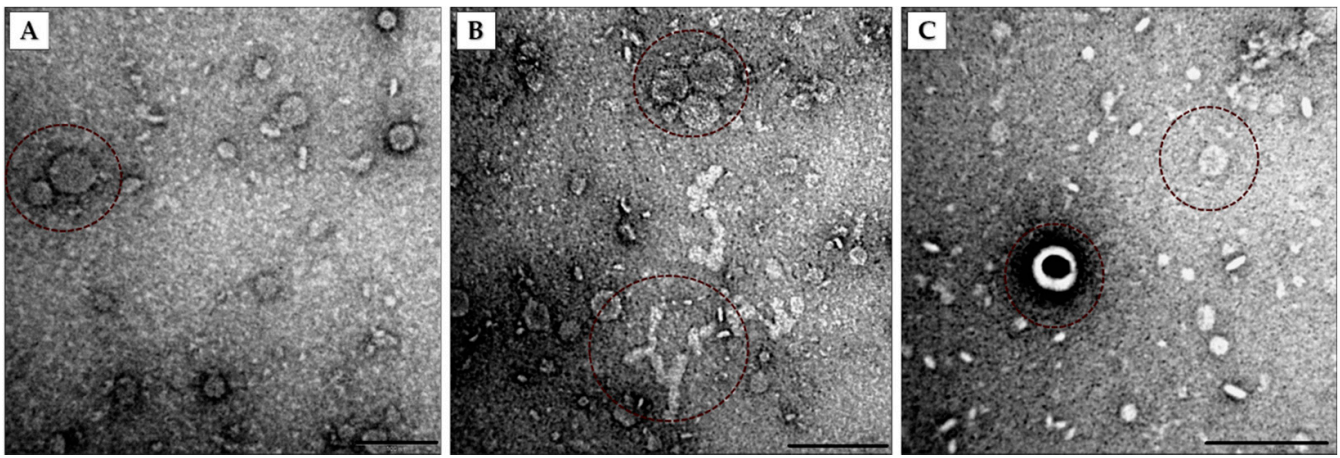

Figure 3. Transmission electron microscopy of OMVs isolated from Pbr1692 in the stationary growth phase. (A) The TEM image shows OMVs of different sizes. (B) The image shows OMV aggregates (top) and the OMV chain-like morphology (bottom). (C) The dotted circles indicate a singlemembrane vesicle and a double-membrane OIMV vesicle with a halo around. Scale bars $=200 \mathrm{~nm}$.

\subsection{Proteomic Analysis of OMVs}

Pbr1692 encodes 4135 proteins in its genome (https: / / www.uniprot.org/proteomes / UP000464068 accessed on 15 June 2021). The TripleTOF 5600 mass spectrophotometer was used to analyze the digested proteins of OMV samples isolated from three independent cultures to produce 119,240 spectra in total. Mascot analysis of the mass spectrometry generated data by searching against a Pbr constructed database was used to identify the OMV proteins. A total of 451 proteins were identified as potential OMV cargo of Pbr1692 in OMV-enriched fractions of three independent culture supernatants (Table 1).

Table 1. Mass spectrometry and Mascot comparison data of Pbr1692 OMVs.

\begin{tabular}{ccccc}
\hline Sample & Total Spectra & $\begin{array}{c}\text { Identified } \\
\text { Spectra }\end{array}$ & $\begin{array}{c}\text { Identified } \\
\text { Peptides }\end{array}$ & $\begin{array}{c}\text { Identified } \\
\text { Proteins }\end{array}$ \\
\hline OMV1 & 40,254 & 1294 & 629 & 241 \\
OMV2 & 39,260 & 1474 & 685 & 262 \\
OMV3 & 39,726 & 2167 & 1002 & 364 \\
Total & 119,240 & 4935 & 2316 & 451 \\
\hline
\end{tabular}

A cut-off of two or more predicted peptides per identified protein was used to filter the proteins identified in the three biological replicates shown in Table 1 . In total, 117, 126, and 171 proteins were considered OMV cargo of OMV1, OMV2, and OMV3, respectively (Figure 4). A total of 114 (97\%) of the 117 proteins identified in OMV1 were present in the other two replicates (Figure 4). Of the 126 proteins identified in the sample OMV2, $109(87 \%)$ were present in the other two replicates. Lastly, among OMV3 proteins, 115 
(67\%) placed in replicate OMV1 and OMV2. OMV1, OMV2 and, OMV3 had 3, 17, and 56 unique proteins, respectively (Figure 4A). A total of 129 proteins present in at least two biological replicates were taken for further analysis as Pbr1692 OMV-associated proteins and cargo (Table S1). The biological replicate protein numbers suggest a high degree of consistency and reproducibility. In total, $80(62 \%)$ of the 129 proteins were present in all three replicates, and $49(38 \%)$ were present in two biological replicates. To predict the subcellular localization of the OMV proteins, PSORTb v3.0.3 was employed. Most of the OMV proteins were outer membrane (28\%) and cytoplasmic proteins (28\%) (Figure 4B). Other locale predictions included cytoplasmic membrane proteins (9\%), extracellular proteins $(14 \%)$, and periplasmic proteins (5\%). Subcellular predictions of $16 \%$ of the OMV proteins were not assigned subcellular localizations.
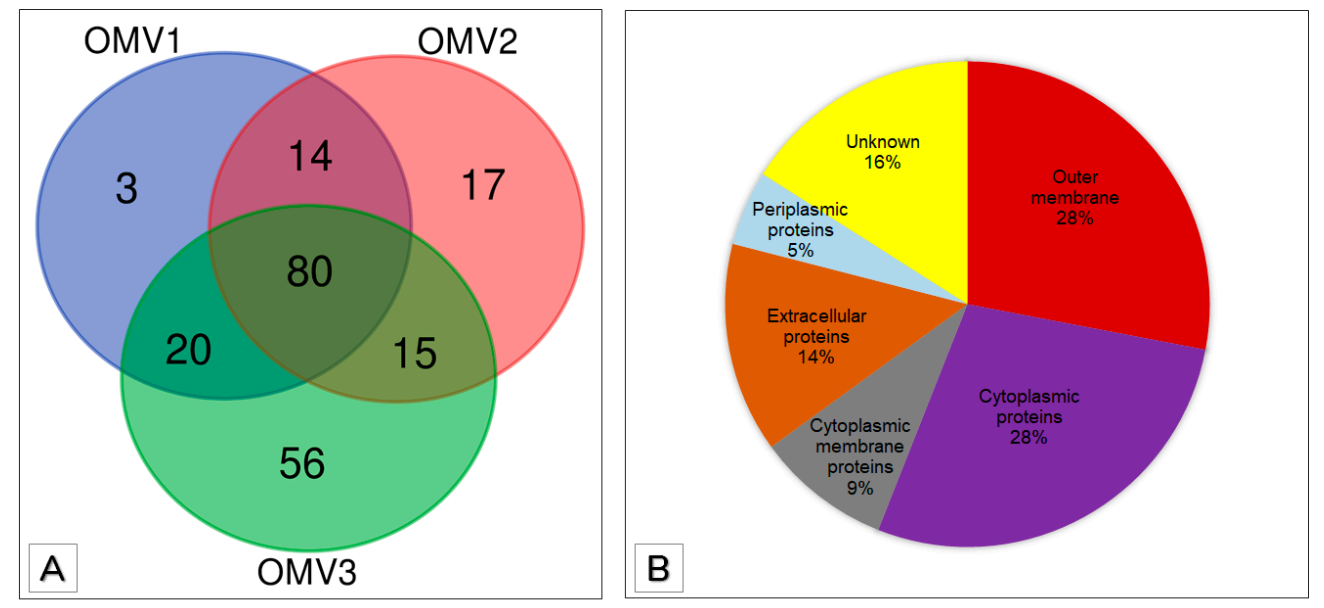

Figure 4. Shared and exclusive OMV-associated proteins of biological replicates and shared protein localization predictions. (A) The Venn diagram indicates shared and exclusive proteins of the three biological replicate OMVs isolated from Pbr1692 cultures. Eighty proteins were found present in all three biological replicates. (B) The pie chart shows the percentages of shared OMV proteins' predicted localizations.

The iBAQ was used to establish the most abundant proteins in OMVs. The top 50 most abundant proteins are shown in Table 2. Among the most abundant proteins, most were outer membrane proteins. Very few proteins in the top 50 were identified as cytoplasmic membrane (3) and periplasmic (1) proteins. Nine proteins in the most abundant OMV proteins had no localization information, according to the PSORTb tool. Gene ontologies were also assigned to the most abundant proteins (Table 2).

Table 2. The top 50 most abundant OMV proteins of Pbr1692 based on iBAQ.

\begin{tabular}{|c|c|c|c|c|c|c|c|c|}
\hline Rank & Protein ID & Description & $\begin{array}{c}\text { Molecular } \\
\text { Weight [kDa] }\end{array}$ & $\begin{array}{c}\text { Protein } \\
\text { Length [aa] }\end{array}$ & $\begin{array}{l}\text { Unique Peptide } \\
\text { Number }\end{array}$ & Gene Ontology IDs & $\begin{array}{c}\text { Final } \\
\text { Localization }\end{array}$ & iBAQ \\
\hline 1 & $\begin{array}{c}\operatorname{tr} \mid \text { A0A6I6X5L4| } \\
\text { A0A6I6X5L4_9GAMM }\end{array}$ & $\begin{array}{l}\text { Uncharacterized } \\
\text { protein }\end{array}$ & 52.67 & 492 & 7 & No information & Unknown & 7865.322 \\
\hline 2 & $\begin{array}{c}\operatorname{tr} \mid \text { A0A086EQL9| } \\
\text { A0A086EQL9_9GAMM }\end{array}$ & $\begin{array}{l}\text { MipA/OmpV } \\
\text { family protein }\end{array}$ & 27.47 & 249 & 6 & GO:0016021 & $\begin{array}{l}\text { Outer } \\
\text { membrane }\end{array}$ & 6915.651 \\
\hline 3 & $\begin{array}{l}\operatorname{tr} \mid \text { A0A0M2F0M9| } \\
\text { A0A0M2F0M9_9GAMM }\end{array}$ & $\begin{array}{l}\text { Phage tail } \\
\text { sheath family } \\
\text { protein }\end{array}$ & 51.19 & 475 & 11 & No information & Unknown & 6680.566 \\
\hline 4 & $\begin{array}{c}\operatorname{tr} \mid \text { A0A6I6XF41 | } \\
\text { A0A6I6XF41_9GAMM }\end{array}$ & Porin & 39.82 & 369 & 12 & $\begin{array}{l}\text { GO:0006811 } \\
\text { GO:0015288 } \\
\text { GO:0009279 } \\
\text { GO:0046930 }\end{array}$ & $\begin{array}{l}\text { Outer } \\
\text { membrane }\end{array}$ & 4079.296 \\
\hline 5 & $\begin{array}{c}\operatorname{tr} \mid \text { A0A3S0ZK54 I } \\
\text { A0A3S0ZK54_9GAMM }\end{array}$ & $\begin{array}{l}\text { Lipoprotein } \\
\text { NlpD }\end{array}$ & 35.59 & 344 & 7 & No information & $\begin{array}{l}\text { Outer } \\
\text { membrane }\end{array}$ & 2786.763 \\
\hline 6 & $\begin{array}{c}\operatorname{tr} \mid \text { A0A0M2F4E7I } \\
\text { A0A0M2F4E7_9GAMM }\end{array}$ & $\begin{array}{l}\text { Avirulence } \\
\text { protein }\end{array}$ & 68.42 & 621 & 15 & No information & Unknown & 2730.042 \\
\hline 7 & $\begin{array}{c}\operatorname{tr} \mid \text { A0A6I6X6T7 | } \\
\text { A0A6I6X6T7_9GAMM }\end{array}$ & Serralysin & 51.22 & 476 & 8 & No information & Extracellular & 2408.248 \\
\hline
\end{tabular}


Table 2. Cont.

\begin{tabular}{|c|c|c|c|c|c|c|c|c|}
\hline Rank & Protein ID & Description & $\begin{array}{c}\text { Molecular } \\
\text { Weight }[\mathrm{kDa}]\end{array}$ & $\begin{array}{c}\text { Protein } \\
\text { Length [aa] }\end{array}$ & $\begin{array}{l}\text { Unique Peptide } \\
\text { Number }\end{array}$ & Gene Ontology IDs & $\begin{array}{c}\text { Final } \\
\text { Localization }\end{array}$ & iBAQ \\
\hline 8 & $\begin{array}{c}\operatorname{tr} \mid \text { A0A6I6X997। } \\
\text { A0A6I6X997_9GAMM }\end{array}$ & Porin & 27.64 & 243 & 4 & No information & $\begin{array}{l}\text { Outer } \\
\text { membrane }\end{array}$ & 2390.189 \\
\hline 9 & $\begin{array}{c}\operatorname{tr} \mid \text { A0A086ESP1 } \mid \\
\text { A0A086ESP1_9GAMM }\end{array}$ & $\begin{array}{l}\text { 30S ribosomal } \\
\text { protein } \mathrm{S} 4\end{array}$ & 23.44 & 206 & 5 & $\begin{array}{l}\text { GO:0003735 } \\
\text { GO:0019843 } \\
\text { GO:0006412 } \\
\text { GO:0015935 }\end{array}$ & Cytoplasmic & 2368.547 \\
\hline 10 & $\begin{array}{l}\operatorname{tr} \mid \text { A0A0M2F5U6 | } \\
\text { A0A0M2F5U6_9GAMM }\end{array}$ & $\begin{array}{l}\text { Tol-Pal system } \\
\text { protein TolB } \\
\text { Endolytic }\end{array}$ & 45.89 & 430 & 8 & $\begin{array}{l}\text { GO:0017038 } \\
\text { GO:0042597 } \\
\text { GO:0071555 }\end{array}$ & Periplasmic & 2326,679 \\
\hline 11 & $\begin{array}{c}\operatorname{tr} \mid \text { A0A6I6WLG2 | } \\
\text { A0A6I6WLG2_9GAMM }\end{array}$ & $\begin{array}{l}\text { peptidoglycan } \\
\text { transglycosy- } \\
\text { lase } \\
\text { RlpA }\end{array}$ & 39.08 & 372 & 9 & $\begin{array}{l}\text { GO:0016829 } \\
\text { GO:0008932 } \\
\text { GO:0000270 } \\
\text { GO:0042834 }\end{array}$ & Extracellular & 2241.485 \\
\hline 12 & $\begin{array}{l}\operatorname{tr} \mid \text { A0A0M2F1K8 | } \\
\text { A0A0M2F1K8_9GAMM }\end{array}$ & $\begin{array}{l}\text { Membrane } \\
\text { protein }\end{array}$ & 18.30 & 171 & 4 & $\begin{array}{l}\text { GO:0016021 } \\
\text { GO:0009279 } \\
\text { GO:0005576 }\end{array}$ & $\begin{array}{l}\text { Outer } \\
\text { membrane }\end{array}$ & 2232.414 \\
\hline 13 & $\begin{array}{c}\operatorname{tr} \mid \text { A0A0M2F2F9 | } \\
\text { A0A0M2F2F9_9GAMM }\end{array}$ & Endoglucanase & 54.91 & 505 & 5 & $\begin{array}{l}\text { GO:0030248 } \\
\text { GO:0008810 } \\
\text { GO:0030245 } \\
\text { GO:0005737 }\end{array}$ & Extracellular & 2195.773 \\
\hline 14 & $\begin{array}{c}\operatorname{tr} \mid \text { A0A3S0ZW77| } \\
\text { A0A3S0ZW77_9GAMM }\end{array}$ & $\begin{array}{l}\text { DNA } \\
\text { protection } \\
\text { during } \\
\text { starvation } \\
\text { protein }\end{array}$ & 18.47 & 167 & 2 & $\begin{array}{l}\text { GO:0016722 } \\
\text { GO:0006879 } \\
\text { GO:0030261 } \\
\text { GO:0008199 } \\
\text { GO:0006950 } \\
\text { GO:0003677 }\end{array}$ & Cytoplasmic & 2130.814 \\
\hline 15 & $\begin{array}{c}\operatorname{tr} \mid \text { A0A6I6X0X5 | } \\
\text { A0A6I6X0X5_9GAMM }\end{array}$ & Porin & 27.26 & 238 & 6 & No information & $\begin{array}{l}\text { Outer } \\
\text { membrane }\end{array}$ & 2073.776 \\
\hline 16 & $\begin{array}{l}\text { tr | A0A6I6WXM4 | } \\
\text { A0A6I6WXM4_9GAMM }\end{array}$ & $\begin{array}{c}\text { TonB- } \\
\text { dependent } \\
\text { siderophore } \\
\text { receptor }\end{array}$ & 85.60 & 782 & 17 & $\begin{array}{l}\text { GO:0005506 } \\
\text { GO:0009279 } \\
\text { GO:0004872 } \\
\text { GO:0015891 }\end{array}$ & $\begin{array}{l}\text { Outer } \\
\text { membrane }\end{array}$ & 2064.695 \\
\hline 17 & $\begin{array}{c}\operatorname{tr} \mid \text { A0A6I6X4V7 | } \\
\text { A0A6I6X4V7_9GAMM }\end{array}$ & $\begin{array}{l}\text { Long-chain } \\
\text { fatty acid } \\
\text { transport } \\
\text { protein }\end{array}$ & 46.74 & 433 & 7 & No information & $\begin{array}{l}\text { Outer } \\
\text { membrane }\end{array}$ & 1905.703 \\
\hline 18 & $\begin{array}{c}\operatorname{tr} \mid \text { A0A0M2F6B4 | } \\
\text { A0A0M2F6B4_9GAMM }\end{array}$ & $\begin{array}{l}\text { Peptidoglycan- } \\
\text { associated } \\
\text { protein OS }\end{array}$ & 18.52 & 170 & 3 & $\begin{array}{l}\text { GO:0016021 } \\
\text { GO:0009279 }\end{array}$ & $\begin{array}{l}\text { Outer } \\
\text { membrane }\end{array}$ & 1732.263 \\
\hline 20 & $\begin{array}{c}\operatorname{tr} \mid \text { A0A0M2F5C1 | } \\
\text { A0A0M2F5C1_9GAMM }\end{array}$ & $\begin{array}{l}30 \text { S ribosomal } \\
\text { protein S21 }\end{array}$ & 57.03 & 548 & 12 & $\begin{array}{l}\text { GO:0003735 } \\
\text { GO:0005840 } \\
\text { GO:0016787 } \\
\text { GO:0005829 } \\
\text { GO:0019843 } \\
\text { GO:0000028 } \\
\text { GO:0044391 } \\
\text { GO:0006412 } \\
\text { GO:0022627 } \\
\text { GO:0005737 } \\
\text { GO:0042026 } \\
\text { GO:0051082 } \\
\text { GO:0005524 }\end{array}$ & Cytoplasmic & 1668.284 \\
\hline 21 & $\begin{array}{c}\operatorname{tr} \mid \text { A0A6I6WLX4 | } \\
\text { A0A6I6WLX4_9GAMM }\end{array}$ & $\begin{array}{c}\text { F5/8 type C } \\
\text { domain- } \\
\text { containing } \\
\text { protein }\end{array}$ & 72.11 & 683 & 8 & No information & Extracellular & 1577.233 \\
\hline 22 & $\begin{array}{c}\operatorname{tr}|\mathrm{A} 0 \mathrm{~A} 0 \mathrm{M} 2 \mathrm{~F} 2 \mathrm{C} 0| \\
\text { A0A0M2F2C0_9GAMM }\end{array}$ & $\begin{array}{l}\text { Glycine zipper } \\
\text { 2TM domain- } \\
\text { containing } \\
\text { protein }\end{array}$ & 15.48 & 155 & 2 & GO:0019867 & $\begin{array}{l}\text { Outer } \\
\text { membrane }\end{array}$ & 1402.157 \\
\hline 23 & $\begin{array}{c}\operatorname{tr} \mid \text { A0A6I6X4G9 | } \\
\text { A0A6I6X4G9_9GAMM }\end{array}$ & $\begin{array}{c}\text { Vitamin B12 } \\
\text { transporter } \\
\text { BtuB }\end{array}$ & 68.71 & 625 & 11 & $\begin{array}{l}\text { GO:0015235 } \\
\text { GO:0046872 } \\
\text { GO:0046930 } \\
\text { GO:0006811 } \\
\text { GO:0015288 } \\
\text { GO:0004872 } \\
\text { GO:0009279 }\end{array}$ & $\begin{array}{l}\text { Outer } \\
\text { membrane }\end{array}$ & 1394.331 \\
\hline 24 & $\begin{array}{c}\operatorname{tr} \mid \text { A0A086EV21 I } \\
\text { A0A086EV21_9GAMM }\end{array}$ & $\begin{array}{c}\text { Major outer } \\
\text { membrane } \\
\text { lipoprotein } \\
\text { Lpp }\end{array}$ & 8.40 & 78 & 2 & $\begin{array}{l}\text { GO:0009279 } \\
\text { GO:0019867 }\end{array}$ & $\begin{array}{l}\text { Outer } \\
\text { membrane }\end{array}$ & 1370.143 \\
\hline 25 & $\begin{array}{c}\operatorname{tr} \mid \text { A0A086EK57| } \\
\text { A0A086EK57_9GAMM }\end{array}$ & $\begin{array}{l}\text { Aspartate } \\
\text { ammonia- } \\
\text { lyase }\end{array}$ & 52.59 & 479 & 2 & $\begin{array}{l}\text { GO:0006099 } \\
\text { GO:0006531 } \\
\text { GO:0008797 }\end{array}$ & Cytoplasmic & 1357.524 \\
\hline 26 & $\begin{array}{c}\operatorname{tr} \mid \text { A0A086ESI7 I } \\
\text { A0A086ESI7_9GAMM }\end{array}$ & $\begin{array}{l}\text { Elongation } \\
\text { factor Tu }\end{array}$ & 43.22 & 394 & 8 & $\begin{array}{l}\text { GO:0005737 } \\
\text { GO:0003746 } \\
\text { GO:0005622 } \\
\text { GO:0003924 } \\
\text { GO:0005525 }\end{array}$ & Cytoplasmic & 1357.145 \\
\hline
\end{tabular}


Table 2. Cont.

\begin{tabular}{|c|c|c|c|c|c|c|c|c|}
\hline Rank & Protein ID & Description & $\begin{array}{c}\text { Molecular } \\
\text { Weight [kDa] }\end{array}$ & $\begin{array}{c}\text { Protein } \\
\text { Length [aa] }\end{array}$ & $\begin{array}{l}\text { Unique Peptide } \\
\text { Number }\end{array}$ & Gene Ontology IDs & $\begin{array}{c}\text { Final } \\
\text { Localization }\end{array}$ & iBAQ \\
\hline 27 & $\begin{array}{c}\operatorname{tr} \mid \text { A0A6I6X1L4 I } \\
\text { A0A6I6X1L4_9GAMM }\end{array}$ & $\begin{array}{l}\text { Arabinogalactan } \\
\text { endo-beta-1,4- } \\
\text { galactanase }\end{array}$ & 56.21 & 507 & 4 & $\begin{array}{l}\text { GO:0015926 } \\
\text { GO:0031218 } \\
\text { GO:0008152 } \\
\text { GO:0003735 }\end{array}$ & $\begin{array}{l}\text { Cytoplasmic } \\
\text { membrane }\end{array}$ & 1346.036 \\
\hline 28 & $\begin{array}{c}\operatorname{tr} \mid \text { A0A086EDQ7 I } \\
\text { A0A086EDQ7_9GAMM }\end{array}$ & $\begin{array}{l}50 S \text { ribosomal } \\
\text { protein L18 OS }\end{array}$ & 12.71 & 117 & 2 & $\begin{array}{l}\text { GO:0019843 } \\
\text { GO:0005840 } \\
\text { GO:0006412 }\end{array}$ & Cytoplasmic & 1340.468 \\
\hline 29 & $\begin{array}{l}\operatorname{tr} \mid \text { A0A0M2EXV1 | } \\
\text { A0A0M2EXV1_9GAMM }\end{array}$ & $\begin{array}{l}\text { Baseplate } \\
\text { protein }\end{array}$ & 20.34 & 193 & 3 & No information & Unknown & 1321.959 \\
\hline 30 & $\begin{array}{c}\operatorname{tr} \mid \text { A0A6I6X2M0 | } \\
\text { A0A6I6X2M0_9GAMM }\end{array}$ & $\begin{array}{l}\text { Flagellar hook- } \\
\text { associated } \\
\text { protein } 1\end{array}$ & 59.66 & 564 & 5 & $\begin{array}{l}\text { GO:0044780 } \\
\text { GO:0005576 } \\
\text { GO:0071973 } \\
\text { GO:0009424 } \\
\text { GO:0005198 }\end{array}$ & Extracellular & 1223.784 \\
\hline 31 & $\begin{array}{c}\operatorname{tr} \mid \text { A0A0M2F0F1 | } \\
\text { A0A0M2F0F1_9GAMM }\end{array}$ & $\begin{array}{l}\text { Membrane } \\
\text { protein }\end{array}$ & 23.01 & 210 & 4 & $\begin{array}{l}\text { GO:0016021 } \\
\text { GO:0009279 }\end{array}$ & $\begin{array}{l}\text { Outer } \\
\text { membrane }\end{array}$ & 1198.896 \\
\hline 32 & $\begin{array}{c}\operatorname{tr} \mid \text { A0A086EVT8। } \\
\text { A0A086EVT8_9GAMM }\end{array}$ & $\begin{array}{l}\text { Membrane } \\
\text { protein }\end{array}$ & 19.83 & 190 & 3 & No information & Unknown & 1155.032 \\
\hline 33 & $\begin{array}{c}\operatorname{tr} \mid \text { A0A6I6X7Z6 | } \\
\text { A0A6I6X7Z6_9GAMM }\end{array}$ & $\begin{array}{l}\text { Phage tail } \\
\text { protein }\end{array}$ & 71.45 & 663 & 8 & No information & Unknown & 1079.253 \\
\hline 34 & $\begin{array}{c}\operatorname{tr} \mid \text { A0A433N765 | } \\
\text { A0A433N765_9GAMM }\end{array}$ & Flagellin & 30.05 & 290 & 7 & $\begin{array}{l}\text { GO:0005576 } \\
\text { GO:0071973 } \\
\text { GO:0009420 } \\
\text { GO:0005198 } \\
\text { GO:0030570 }\end{array}$ & Extracellular & 1071.265 \\
\hline 35 & $\begin{array}{l}\operatorname{tr} \mid \mathrm{A} 0 \mathrm{~A} 0 \mathrm{M} 2 \mathrm{~F} 3 \mathrm{M} 0 \text { | } \\
\text { A0A0M2F3M0_9GAMM }\end{array}$ & Pectate lyase & 40.57 & 374 & 5 & $\begin{array}{l}\text { GO:0016829 } \\
\text { GO:0000272 } \\
\text { GO:0005576 } \\
\text { GO:0045490 } \\
\text { GO:0046872 }\end{array}$ & Extracellular & 979.6334 \\
\hline 36 & $\begin{array}{c}\operatorname{tr} \mid \text { A0A0M2F635 | } \\
\text { A0A0M2F635_9GAMM }\end{array}$ & $\begin{array}{l}\text { Membrane } \\
\text { protein }\end{array}$ & 50.45 & 463 & 7 & $\begin{array}{l}\text { GO:0005215 } \\
\text { GO:0019867 }\end{array}$ & $\begin{array}{l}\text { Outer } \\
\text { membrane }\end{array}$ & 906.776 \\
\hline 37 & $\begin{array}{c}\operatorname{tr} \mid \text { A0A6I6X7V5 | } \\
\text { A0A6I6X7V5_9GAMM }\end{array}$ & $\begin{array}{l}\text { TonB- } \\
\text { dependent } \\
\text { receptor }\end{array}$ & 78.19 & 701 & 6 & $\begin{array}{l}\text { GO:0006810 } \\
\text { GO:0009279 } \\
\text { GO:0004872 }\end{array}$ & $\begin{array}{l}\text { Outer } \\
\text { membrane }\end{array}$ & 887.6531 \\
\hline 38 & $\begin{array}{c}\operatorname{tr} \mid \text { A0A433N6R3 | } \\
\text { A0A433N6R3_9GAMM }\end{array}$ & $\begin{array}{l}\text { Flagellar hook- } \\
\text { associated } \\
\text { protein } 2\end{array}$ & 50.76 & 474 & 9 & $\begin{array}{l}\text { GO:0007155 } \\
\text { GO:0005576 } \\
\text { GO:0009424 }\end{array}$ & Extracellular & 871.272 \\
\hline 39 & $\begin{array}{c}\operatorname{tr} \mid \text { A0A086EFY4 | } \\
\text { A0A086EFY4_9GAMM }\end{array}$ & $\begin{array}{l}\text { 50S ribosomal } \\
\text { protein L17 }\end{array}$ & 14.73 & 130 & 3 & $\begin{array}{l}\text { GO:0003735 } \\
\text { GO:0005840 } \\
\text { GO:0006412 }\end{array}$ & Cytoplasmic & 870.2862 \\
\hline 40 & $\begin{array}{c}\operatorname{tr} \mid \text { A0A6I6WY80 | } \\
\text { A0A6I6WY80_9GAMM }\end{array}$ & Pectate lyase & 40.45 & 375 & 5 & $\begin{array}{l}\text { GO:0016829 } \\
\text { GO:0005576 } \\
\text { GO:0000272 }\end{array}$ & Extracellular & 836.9782 \\
\hline 41 & $\begin{array}{c}\operatorname{tr} \mid \text { A0A086EHI7 | } \\
\text { A0A086EHI7_9GAMM }\end{array}$ & $\begin{array}{l}\text { Membrane- } \\
\text { bound lytic } \\
\text { murein transg- } \\
\text { lycosylase }\end{array}$ & 39.88 & 357 & 3 & $\begin{array}{l}\text { GO:0008933 } \\
\text { GO:0016998 } \\
\text { GO:0000270 } \\
\text { GO:0071555 } \\
\text { GO:0009279 }\end{array}$ & Unknown & 805.2442 \\
\hline 42 & $\begin{array}{c}\operatorname{tr} \mid \text { A0A0M2F7U3 | } \\
\text { A0A0M2F7U3_9GAMM }\end{array}$ & $\begin{array}{l}\text { Penicillin- } \\
\text { binding } \\
\text { protein } \\
\text { activator } \\
\text { LpoA }\end{array}$ & 72.40 & 672 & 5 & $\begin{array}{l}\text { GO:0031241 } \\
\text { GO:0030234 } \\
\text { GO:0008360 } \\
\text { GO:0009252 }\end{array}$ & Unknown & 770.3906 \\
\hline 43 & $\begin{array}{c}\operatorname{tr} \mid \text { A0A086ESF5 | } \\
\text { A0A086ESF5_9GAMM }\end{array}$ & Pectate lyase & 40.21 & 374 & 5 & $\begin{array}{l}\text { GO:0030570 } \\
\text { GO:0016829 } \\
\text { GO:0000272 } \\
\text { GO:0005576 } \\
\text { GO:0045490 } \\
\text { GO:0046872 }\end{array}$ & Extracellular & 746.1676 \\
\hline 44 & $\begin{array}{l}\text { tr | A0A0M2EW43 | } \\
\text { A0A0M2EW43_9GAMM }\end{array}$ & $\begin{array}{l}\text { Phosphate- } \\
\text { binding } \\
\text { protein PstS }\end{array}$ & 36.84 & 346 & 5 & $\begin{array}{l}\text { GO:0043190 } \\
\text { GO:0035435 } \\
\text { GO:0042301 }\end{array}$ & Unknown & 743.0872 \\
\hline 45 & $\begin{array}{l}\operatorname{tr} \mid \text { A0A0M2F4N0 | } \\
\text { A0A0M2F4N0_9GAMM }\end{array}$ & $\begin{array}{l}\text { Phospholipase } \\
\text { A1 }\end{array}$ & 33.35 & 290 & 3 & $\begin{array}{l}\text { GO:0006629 } \\
\text { GO:0008970 } \\
\text { GO:0016020 } \\
\text { GO:0052739 } \\
\text { GO:0102567 } \\
\text { GO:0102568 } \\
\text { GO:0004623 } \\
\text { GO:0052740 }\end{array}$ & $\begin{array}{l}\text { Outer } \\
\text { membrane }\end{array}$ & 650.1864 \\
\hline
\end{tabular}


Table 2. Cont.

\begin{tabular}{|c|c|c|c|c|c|c|c|c|}
\hline Rank & Protein ID & Description & $\begin{array}{c}\text { Molecular } \\
\text { Weight [kDa] }\end{array}$ & $\begin{array}{c}\text { Protein } \\
\text { Length [aa] }\end{array}$ & $\begin{array}{l}\text { Unique Peptide } \\
\text { Number }\end{array}$ & Gene Ontology IDs & $\begin{array}{c}\text { Final } \\
\text { Localization }\end{array}$ & iBAQ \\
\hline 46 & $\begin{array}{c}\operatorname{tr} \mid \text { A0A086EA76 | } \\
\text { A0A086EA76_9GAMM }\end{array}$ & $\begin{array}{l}\text { Ribose- } \\
\text { phosphate } \\
\text { pyrophospho- } \\
\text { kinase }\end{array}$ & 34.34 & 315 & 3 & $\begin{array}{l}\text { GO:0005737 } \\
\text { GO:0016301 } \\
\text { GO:0009156 } \\
\text { GO:0000287 } \\
\text { GO:0004749 } \\
\text { GO:0009165 } \\
\text { GO:0009116 } \\
\text { GO:0006015 } \\
\text { GO:0005524 }\end{array}$ & Cytoplasmic & 648.6135 \\
\hline 47 & $\begin{array}{c}\operatorname{tr} \mid \text { A0A086EWE3 | } \\
\text { A0A086EWE3_9GAMM }\end{array}$ & $\begin{array}{c}\text { Outer } \\
\text { membrane } \\
\text { protein } \\
\text { assembly } \\
\text { factor BamA }\end{array}$ & 89.09 & 810 & 5 & $\begin{array}{l}\text { GO:0051205 } \\
\text { GO:0016021 } \\
\text { GO:0009279 } \\
\text { GO:0043165 }\end{array}$ & $\begin{array}{l}\text { Outer } \\
\text { membrane }\end{array}$ & 646.6694 \\
\hline 48 & $\begin{array}{c}\operatorname{tr} \mid \text { A0A433N5X5 | } \\
\text { A0A433N5X5_9GAMM }\end{array}$ & $\begin{array}{c}\text { Putative } \\
\text { lipoprotein } \\
\text { YajI }\end{array}$ & 20.43 & 189 & 2 & No information & $\begin{array}{l}\text { Cytoplasmic } \\
\text { membrane }\end{array}$ & 628.1156 \\
\hline 49 & $\begin{array}{c}\operatorname{tr} \mid \text { A0A086E9U3 | } \\
\text { A0A086E9U3_9GAMM }\end{array}$ & $\begin{array}{l}\text { LPS-assembly } \\
\text { lipoprotein } \\
\text { LptE }\end{array}$ & 20.37 & 184 & 3 & $\begin{array}{l}\text { GO:0009279 } \\
\text { GO:0043165 }\end{array}$ & $\begin{array}{l}\text { Outer } \\
\text { membrane }\end{array}$ & 617.4362 \\
\hline 50 & $\begin{array}{c}\text { tr | A0A3S1FKD4 | } \\
\text { A0A3S1FKD4_9GAMM }\end{array}$ & $\begin{array}{l}\text { Penicillin- } \\
\text { binding } \\
\text { protein 1B }\end{array}$ & 92.49 & 826 & 4 & $\begin{array}{l}\text { GO:0009252 } \\
\text { GO:0008955 } \\
\text { GO:0016021 } \\
\text { GO:0008658 } \\
\text { GO:0071555 } \\
\text { GO:0008360 } \\
\text { GO:0046677 } \\
\text { GO:0009274 } \\
\text { GO:0008233 }\end{array}$ & $\begin{array}{l}\text { Cytoplasmic } \\
\text { membrane }\end{array}$ & 312.0136 \\
\hline
\end{tabular}

\subsection{Functional Annotation of OMV Proteins}

Gene Ontology (GO), Clusters of Orthologous Groups (COG), Carbohydrate Active enZYme (CAZyme), Virulence Factor DataBase (VFDB) integrated with VFanalyzer, Antibiotic Resistance Ontology (ARO), and Bastion6 T6SE annotations were employed to describe the potential functions of the OMV proteins. Proteins were annotated in GO terms to comprehensively provide all possible claims of their properties within the following ontologies: molecular, cellular, and biological process functions. In total, $240 \mathrm{GO}$ annotations were assigned to 104 OMV proteins. The WEGO output (https:/ / wego.genomics.cn/ accessed on 26 April 2021) was used to visualize the respective ontology entries of the proteins with assigned GO terms within the three ontologies and the number of proteins associated with each group. A total of 81 biological functions and 80 cellular component functions were assigned. Under the ontology of biological processes, the highest number of proteins was found in annotated cellular (GO:0009987) and metabolic process (GO:0008152) functions. The cellular component terms cell (GO:0005623) and cell part (GO:0044464) represented $59.6 \%$ and $58.7 \%$, respectively.

A total of 79 molecular function GO annotations were assigned (Figure $5 \mathrm{~A}$ ). In total, $56(53.8 \%)$ of the 104 proteins were assigned catalytic activity functions (GO:0003824). The most abundant in this entry had hydrolase (GO:0016787), transferase (GO:0016740), and lyase (GO:0016829) activity. Proteins exhibiting phospholipase A1 or A2 activity, polygalacturonase activity, peptidase activity, and cellulase activity were among the identified hydrolases. Nine proteins $(8.7 \%)$, six $(5.8 \%)$, and three $(2.9 \%)$ were annotated oxidoreductase activity, catalytic activity acting on a protein, and peptidoglycan muralytic activity, respectively. Forty-two proteins exhibiting binding ability (GO:0005488) made 40.2\% of the total number of annotated proteins. Seven $(6.7 \%)$ proteins were annotated drug binding activity. Other entries in the molecular ontology included structural molecule activity (GO:0005198), transporter activity (GO:0005215), a molecular function regulator role (GO:0098772), and antioxidant activity (GO:0016209). Sets of COGs established more useful classification clues (Figure 5B). COGs linked the proteins to an evolutionary trail to clarify the proteins' roles. The cluster with the highest number of proteins included cell wall/membrane/envelope biogenesis groups. Relatively high numbers were also assigned to groups with carbohydrate transport and metabolism, energy production and conver- 
sions, and inorganic ion transport and metabolism functions. COG analysis predicted generalized positions for eight proteins and did not establish cluster links for 13 proteins. The other protein cluster groups identified are shown in Figure 5B.
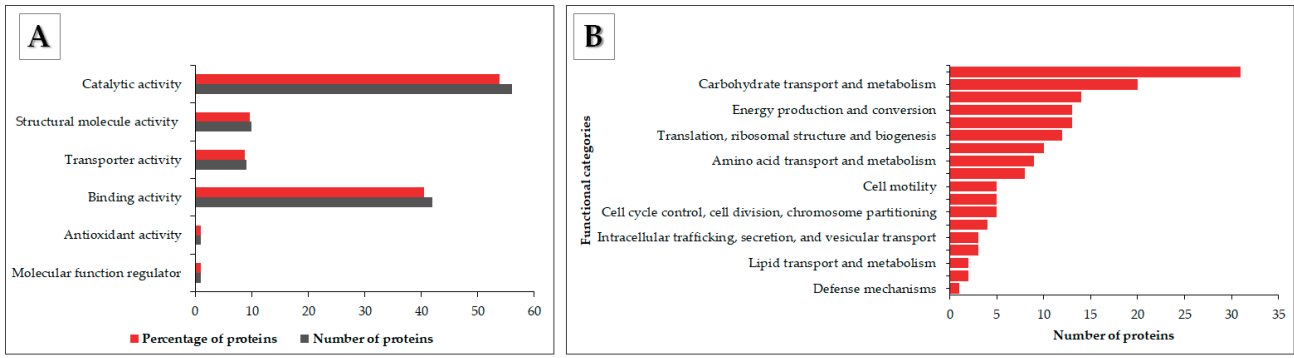

Figure 5. OMV protein molecular functions and protein COG classification. (A). The graph shows the molecular ontology entries against the number and percentage of associated proteins. (B) The chart shows protein functional group categories and the corresponding number of proteins associated with each cluster.

3.5. Identification of OMV Virulence Factors, Carbohydrate-Active Proteins, Antibiotic Agents, and T6SES

We established further which OMV proteins exhibit virulence, carbohydrate-active, antibiotic resistance, and antibiotic properties (Figure 6).

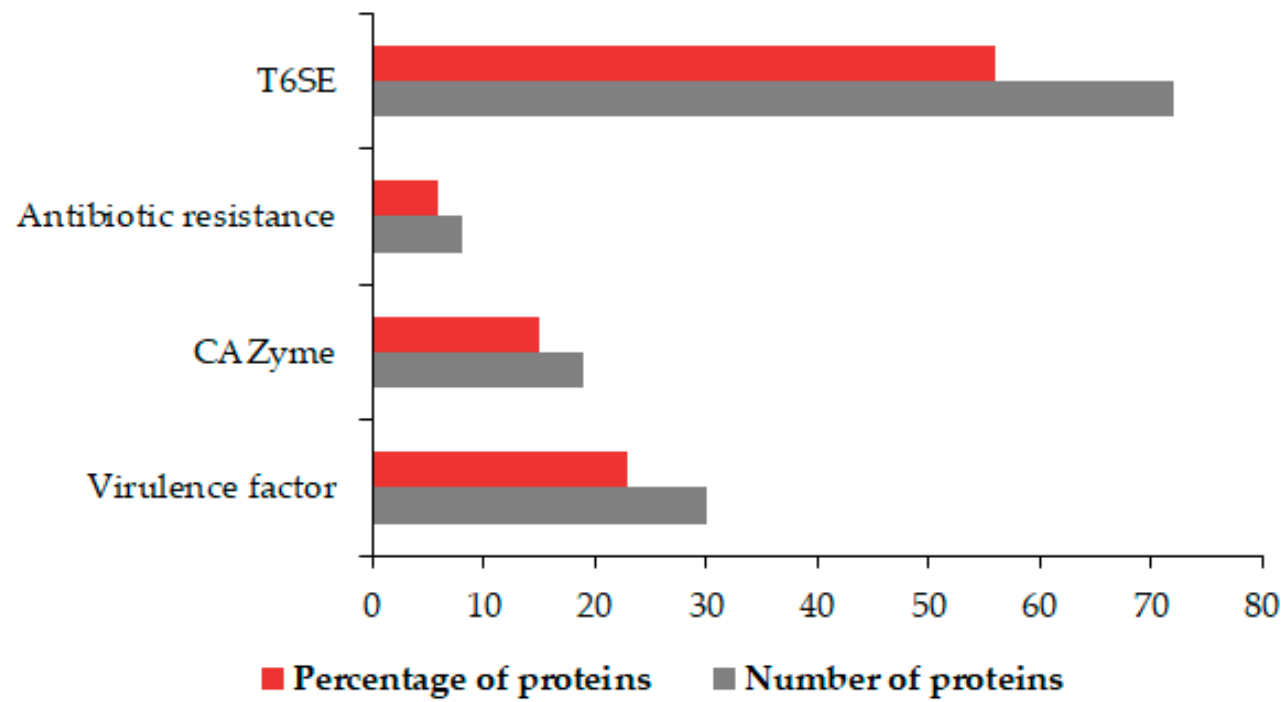

Figure 6. OMV proteins associated with virulence, carbohydrate metabolism, stress resistance, and competition. The graph shows the number and percentages of OMV virulence factors, CAZymes, antibiotic resistance agents, and T6SE.

Thirty-one virulence proteins were identified using the Virulence Factor DataBase (VFDB). The identified Virulence Factors (VF) included six pectate lyases with carbohydrate metabolism roles, attachment invasion locus protein, adhesin, and ATPase activity. Other VF proteins found had catalase $(\operatorname{tr} \mid$ A0A0M2F307 | A0A0M2F307_9GAMM), esterase (EstA) ( $\operatorname{tr} \mid$ A0A0M2F3J1 | A0A0M2F3J1_9GAMM), and contact-dependent inhibition A (CdiA) ( $\operatorname{tr} \mid$ A0A0M2EZM6 | A0A0M2EZM6_9GAMM) activity. The elongation factor (EF-Tu) and flagellin were also among identified VFs. Twenty-one enzymes important in carbohydrate metabolism were identified. We also identified two $\mathrm{F} 5 / 8$ type $\mathrm{C}$ domain-containing proteins, arabinogalactan endo-beta-1,4-galactanase, endoglucanase, and membrane-bound lytic murein transglycosylase each. Other enzymes were peptidoglycan lytic exotransglycylase, glycoside hydrolase, murein transglycosylase B, penicillin-binding protein, endopolygalacturonase, exo-poly-alpha-D-galacturonidase, and an autotransporter protein. 
The comprehensive antibiotic resistance database (CARD) was used to identify proteins involved in bacterial antimicrobial resistance; hence, such proteins are instrumental in survival. Eight proteins, namely, OmpA, OmpK, LptD, RspA, SecD, FusA, and TolC, were identified. These eight proteins were predicted to facilitate antibiotic efflux, alter the antibiotic target, and reduce permeability to the antibiotic. LptD was among nine out of 72 proteins we identified with a probability $>0.9$ to be T6SEs. A phospholipase effector and the avirulence protein, suspected to induce HR in plant hosts, were also identified. Other proteins included porins, a phage tail protein, a YjbH domain-containing protein, and TonB dependent plug domain-containing protein.

\subsection{Contribution of Pbr1692 OMVs to Virulence and Hypersensitive Response}

Using gelatine as the protease target substrate, zymography validated the protease activity of OMVs. In this regard, OMVs displayed a $~ 55 \mathrm{KDa}$ protein demonstrating gelatine hydrolysis of the gelatine incorporated in the gel shown by the white zone clearing at this site (Figure 7A). On the contrary, no activity was observed for denatured/heat-inactivated OMVs (negative control) (Figure 7). Further, OMV cargo macerated tissue of susceptible Solanum tuberosum L. cv Mondial three days post-inoculation (Figure 7B). As expected, the maceration degree was highest when potatoes were inoculated with Pbr1692 cells as a positive control compared to cell-free supernatant or OMV cargo (Figure 7B). OMVs and Pbr1692 supernatant also elicited HR, visible at $24 \mathrm{hpi}$. On the other hand, no activity was observed for the OMV supernatant obtained after the second OMV washing step, implying that all loosely associated proteins were successfully removed and the OMV cargo specifically inflicts observed phenotypes (Figure 7C).

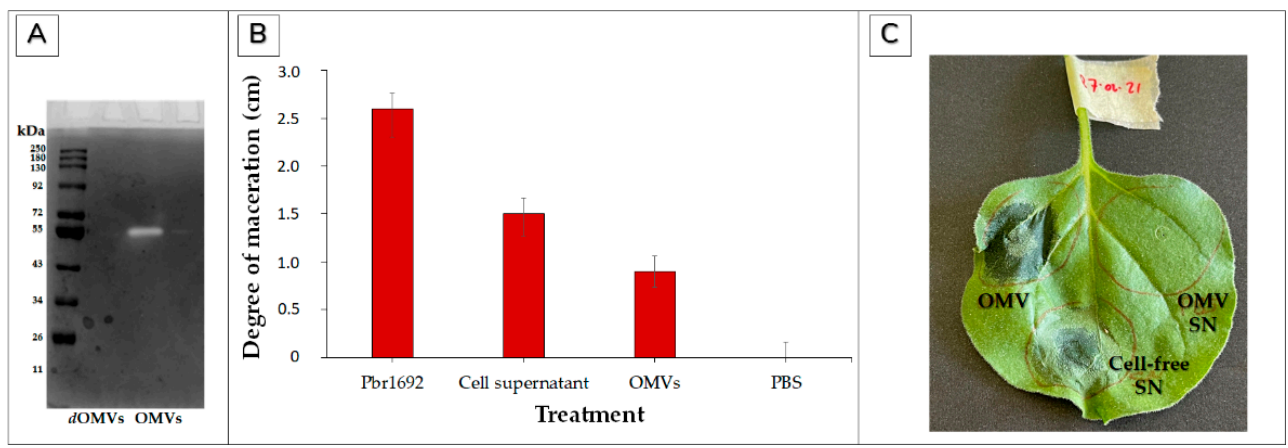

Figure 7. Virulence activities of Pbr1692 OMVs. (A) OMV protease activity. A $12 \%$ SDS PAGE zymogram gel shows Pbr1692 OMV digestion of gelatine via protease activity. Gelatinase digestion by the OMVs is demonstrated by the white band clearing zone corresponding to a $\sim 55 \mathrm{kDa}$ protein by visualization using Coomassie Brilliant blue staining. Denatured OMVs were used as a negative control. $\mathrm{M}=$ marker; dOMVs = denatured OMVs. (B) Soft rot of potato tubers by Pbr1692 OMVs. The figure shows OMV-associated maceration of potato tuber tissue three days post-inoculation. The cell-free supernatant was used as the positive control, while PBS was used as a negative control. The results show the means of two independent experiments. Error bars represent the standard deviations from the data. Differences between the effect of the control and OMVs were determined to be statistically significant with $p<0.01$. (C) OMVs elicited a hypersensitive response (HR) in 2-week-old seedlings of $N$. benthamiana 24 hpi. The OMV wash step SN and cell-free supernatant were used as controls.

\subsection{Antimicrobial Activity of OMVs against Dickeya dadantii}

We explored the possibility that the OMVs carry bacterial growth inhibitory components previously shown to give Pbr1692 a competitive advantage against other bacteria [40]. OMVs isolated from the Pbr1692 culture exhibited antibacterial activity against $D$. dadantii, another soft rot pathogen found within the microbial community during potato infection. OMVs reduced the D. dadantii cells by approximately $95 \%$ (Figure 8 ). As expected, the 
proliferation of $D$. dadantii was highly inhibited by Pbr1692 as a positive control compared to when $D$. dadantii was cocultured with PBS as a negative control.

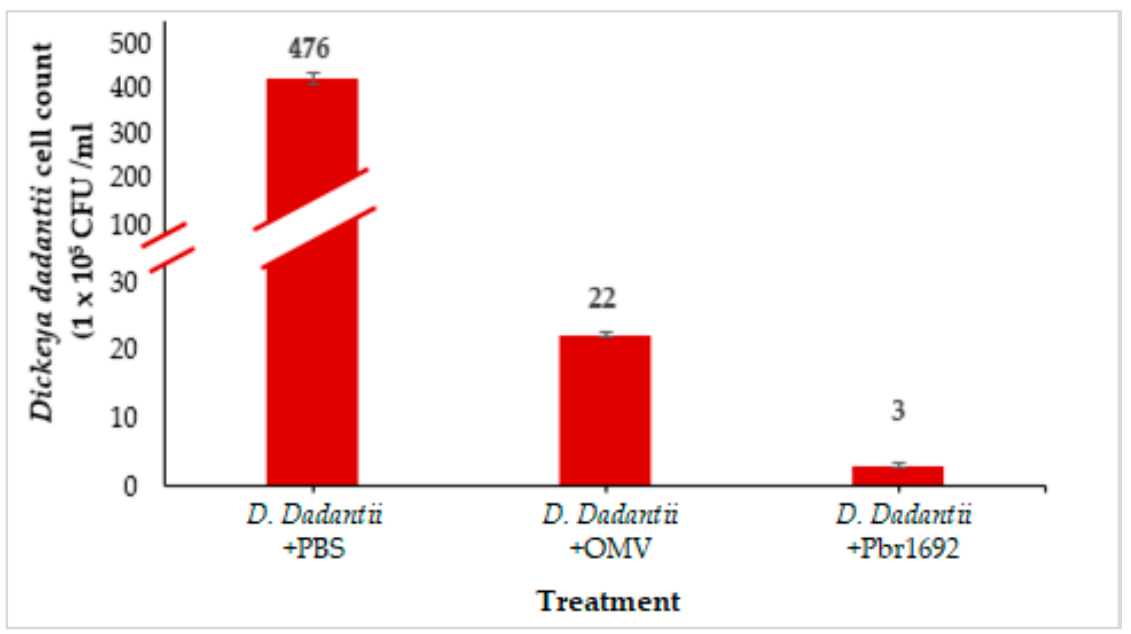

Figure 8. Antimicrobial activity of OMVs. The graph shows D. dadantii cells cocultured with PBS as a negative control and its growth inhibition in the presence of Pbr1692 OMVs and Pbr1692 cells. The results show the means of two independent experiments. Error bars represent the standard deviations from the data. Differences between the effect of the PBS-negative control with Pbr1692 cells and OMVs on $D$. dadantii was determined to be statistically significant with $p<0.01$ in the analysis of variance.

\section{Discussion}

The secretion systems of GNB deliver proteins to different host cell compartments and into the external milieu to invade and evade the host, alienate competitors, and maximize resource usage [12]. However, only a handful of reports contribute to current knowledge of the role of OMVs, specifically those of phytopathogens, in this regard. Since Pbr1692 is an important phytopathogen of potatoes, we were interested in determining the type of vesicles it produces, the cargo ferried by these vesicles, and the potential roles they may play in the biology of this pathogen. Towards this end, we found that in nutritionally rich media, OMVs naturally emerge from distinct areas of Pbr1692 cells during in vitro growth, suggesting that there are dedicated "hot spots" of membrane blebbing. OMVs do not form spontaneously; hence, "hot spots" may be required to maintain cell viability during vesiculation [51]. Vesicles were also embedded in a biofilm-like matrix and, thus, are possible 'nucleation' biofilm centers from which biofilm formation can be centered [41,52-55]. In our previous studies, we found that part of the strategy used by Pbr1692 to invade potato stem xylem tissue is forming biofilms [56,57]. This study brings new insights into the possible contribution of OMVs towards Pbr1692 biofilm formation. In the current study, we found that Pbr1692 produces OMVs and OIMVs. A similar observation was previously reported for Pectobacterium betavasculorum IFB5271 and Pectobacterium zantedeschiae 9M (formerly P. atrosepticum) [11]. The presence of OIMVs makes it difficult to dismiss cytoplasmic proteins, RNA, and DNA as cell lysis contaminants in vesicle preparations $[11,58]$. Moreover, OIMV constituents seem sensitive; hence, they are enclosed in a double membrane. OIMV production is, thus, specialized, possibly through circularizing membranes of dead cell minority entrapping cytoplasmic proteins and nucleic acids [58]. In contrast to localized blebbing from "hot spots", explosive or endolysintriggered cell lysis is a novel biogenesis mode of EOMVs and OIMVs containing periplasmic and cytoplasmic proteins $[11,16,17]$. There is also sufficient evidence of moonlighting cytosolic proteins and DNA that function on the bacterial cell surface associated with OMVs $[59,60]$. Other membrane vesicle types and extensions are nano pods, nanotubes, and nanowires $[15,20]$. Chain-like OMVs and OMV aggregates were observed in this 
study. Cell-cell communication bridging is assumed to be the reason for the chain-like phenotype [19].

A total of 129 proteins associated with Pbr1692 OMVs was identified. This number compares fairly to other studies, such as one involving Xylella fastidiosa, despite differences in culture growth conditions, OMV sizes, and cargo [41,61,62]. The only other study involving Pectobacterium spp vesicles using P. betavasculorum IFB5271 and P. zantedeschiae 9M identified 62 proteins, nearly half the number of proteins identified here [11]. With regard to cargo, most of the proteins identified were outer membrane (36) and cytoplasmic proteins (36). The latter, in early studies, were considered unexpected OMV cargo since OMVs predominantly carried periplasmic and outer membrane components [63]. Extracellular proteins (21) were also found in relatively high numbers as part of OMV cargo. This is not surprising since Pbr1692 directs its extracellular enzymes into the periplasmic space for delivery via the T2SS into the extracellular environment [64]. Therefore, proteins enriched in the periplasm have a higher probability of being loaded into single-membrane vesicles produced by this bacterium.

Among the top 50 most abundant proteins mapped in this study (Table 2), there was a high number of cell and cell part annotated proteins. These included outer membrane proteins, which are generally essential as barriers against stressful conditions. Therefore, this points to a protective role of OMVs to their cargo and producing organism [27]. Among the OMV proteins, antibiotic resistance and nutrient acquisition-related outer membrane proteins critical for survival through roles such as decreasing porin production to reduce the pathogen's susceptibility to antibiotics and increased membrane integrity were also represented [11,34,65-67].

OMV functions currently include pathogenesis, inter- or intraspecies communication, and survival reviewed in [14,32]. Phytopathogen OMV-associated roles include biofilm formation, modulation of plant immunity, and virulence; hence, they are predicted to be intrinsic to their biology, as reviewed by [25]. For example, Xanthomonas campestris, $X$. fastidiosa, and Pseudomonas syringae pv. tomato T1 are among GNB that release OMVs that contain various virulence factors [24,68-70]. Therefore, we expected that OMVs exhibit significance in the fitness of Pbr1692 within microbial communities, its host adaptation, and particularly in virulence as in the other Pectobacterium spp. [11]. The protection conferred by vesicles ensures the long-distance delivery of proteins shielded from proteases in the environment [20]. In this study, several PCWDEs and proteases (Pel, Peh, Cel, Prt) were identified virulence factors in OMVs. Moreover, the presence of PCWDEs in OMVs coincided with the abundant oligogalacturonide specific porin (KdgM). KdgM is required to uptake the cell wall degradation products used as a carbon source for bacterial growth after its maceration by PCWDEs [66]. We validated this finding by showing that OMV cargo macerates potato tuber tissue of a high moisture and low starch content susceptible Solanum tuberosum L. cv Mondial three days post-inoculation. The degree of maceration by OMVs compared with Pbr1692 cells and the cell-free supernatant emphasized that OMVs contribute as a secretion system.

The OMV proteome profile generated in this study also shows that OMVs carry highly conserved pathogen-associated molecular patterns (PAMPS) known to interact with plant recognition receptors (PRR) to alert the plant's innate immune system of an attack [26]. In this regard, two flagella proteins were identified in the proteome of Pbr1692 OMVs [26]. Another PAMP found in the OMV proteome was the Elongation factor Tu (EF-Tu). These factors could have contributed to Pbr1692 OMVs' ability to elicit an immune response in N. benthamiana. Other studies characterizing OMV functional roles in phytopathogenesis have also discovered PAMPs such as EF-Tu and polysaccharide A, indicating that vesicles have a conserved mechanism for delivering immunomodulatory molecules from the pathogen to the host [71]. In addition, an avirulence protein whose canonical secretion system is the T2SS was also implicated in inducing HR. Pbr1692 AvrL $(\operatorname{tr} \mid$ A0A0M2F4E7 | A0A0M2F4E7_9GAMM) is a homolog of the virulence protein Svx in 
Pectobacterium atrosepticum and an ortholog of AvrM in D. dadantii, and both were previously reported to be upregulated in planta [72,73].

Previously, we showed that Pbr1692 has the ability to inhibit the growth of Dickeya spp. and other bacteria in vitro or during the infection of its host [40]. Pbr1692 produces phospholipases and other antimicrobial substances, namely, bacteriocins and carbapenem, to kill competitive bacteria. It is possible that this killing is necessitated due to the high demand for nutrients, including iron. As both $D$. dadantii and Pbr typically share the same niche, the challenge posed by $D$. dadantii to Pbr1692 is that PCWDE regulation is often coupled with iron acquisition; hence, there is competition for the available iron and other nutrients [74]. For this reason, Pbr1692 can eliminate its competitors such as $D$. dadantii through the release of toxins. Towards this end, OMVs have a fitness and survival role in these complex microbial communities [7]. As such, our proteomics data reveal that OMVs produced by Pbr1692 contain the CdiA effector ( $\operatorname{tr} \mid$ A0A0M2EZM6 | A0A0M2EZM6_9GAMM) that causes contactdependent growth inhibition (CDI). CdiA toxins bind to specific receptors on target bacteria to deliver C-terminal toxin domains to suppress target cell growth [75]. In addition, an antibacterial T6SS substrate, Phospholipase A1 ( $\operatorname{tr} \mid$ A0A0M2F4N0 | A0A0M2F4N0_9GAMM), was identified with a probability score of 0.886 among the 72 identified OMV and Type 6 Secreted Effector proteins in this study. Predictably, we showed that OMVs isolated from the Pbr1692 culture had antiproliferative effects on $D$. dadantii. OMVs reduced the $D$. dadantii cells by approximately $95 \%$.

Amid the host-pathogen arms race, antibiotics, hot water, UV light, bacteriophages, and steam treatments are among strategies that have been explored to control Pectobacterium spp. [76]. OMV deflect bacteriophage attention and mediate antibiotic resistance [19,77]. We predicted that Pbr1692 OMV cargo OmpA, OmpK, TolC, and LptD facilitate resistance to carbapenem, an antibiotic that Pbr1692 itself produces and charges at target competitor bacteria via the T6SS [40].

\section{Conclusions}

We demonstrated that Pbr1692 formed double- and single-membrane OMVs and defined their roles in infection and survival. OMVs appear to be enhancers of Pbr1692's secretion systems, as shown by their diversified cargo dedicated to bacterial virulence and overall fitness in their ecological niche. The diversity also raises concerns regarding the strictness of this secretion system's cargo selection based on its leader sequenceindependent secretion. This study has provided additional knowledge about the importance of specific proteins, including some CAZymes, antibiotic agents, and T6SEs selected for non-classical secretion in addition to classical secretion by Pbr1692. This work also serves as a springboard for further investigation of OMV crosstalk with the other secretion systems of GNB, such as the T6SS, in the dedicated delivery of anti-plant host effectors.

Supplementary Materials: The following are available online at https:/ / www.mdpi.com/article/10 .3390/microorganisms9091918/s1, Figure S1: Size distribution and concentration of nanoparticles in cell-free supernatants of exponential and stationary phase Pbr1692 cultures; Table S1: Pectobacterium brasiliense 1692 Outer Membrane Vesicle associated proteins.

Author Contributions: Conceptualization, S.M. and L.N.M.; Formal analysis, S.M. and L.N.M.; Funding acquisition, L.N.M.; In-vestigation, S.M. and L.N.M.; Methodology, S.M. and L.N.M.; Project administration, S.M. and L.N.M.; Resources, S.M. and L.N.M.; Supervision, L.N.M.; Validation, S.M. and L.N.M.; Visualiza-tion, S.M.; Writing-original draft, S.M.; Writing—review \& editing, S.M. and L.N.M. All authors have read and agreed to the published version of the manuscript.

Funding: This research was funded by the National Research Foundation (NRF) Competitive Funding for Rated Researchers (120858) South Africa. S. Maphosa was funded by DAAD: German Academic Exchange Service (57408861). All findings, viewpoints, deductions, and recommendations in this material are those of the author(s), and the NRF does not accept any liability in this regard.

Institutional Review Board Statement: Not applicable. 
Informed Consent Statement: Not applicable.

Data Availability Statement: The data presented in this study are openly available in [FigShare] at https:/ / doi.org/10.6084/m9.figshare.16573673.v2.

Conflicts of Interest: The authors declare no conflict of interest.

\section{References}

1. Chang, J.H.; Desveaux, D.; Creason, A.L. The ABCs and 123s of bacterial secretion systems in plant pathogenesis. Annu. Rev. Phytopathol. 2014, 52, 317-345. [CrossRef]

2. Charkowski, A.O. The changing face of bacterial soft-rot diseases. Annu. Rev. Phytopathol. 2018, 56, 269-288. [CrossRef]

3. Zaczek-Moczydłowska, M.A.; Fleming, C.C.; Young, G.K.; Campbell, K.; O’Hanlon, R. Pectobacterium and Dickeya species detected in vegetables in Northern Ireland. Eur. J. Plant Pathol. 2019, 154, 635-647. [CrossRef]

4. Van der Merwe, J.J.; Coutinho, T.A.; Korsten, L.; van der Waals, J.E. Pectobacterium carotovorum subsp. brasiliensis causing blackleg on potatoes in South Africa. Eur. J. Plant Pathol. 2010, 126, 175-185. [CrossRef]

5. Onkendi, E.M.; Moleleki, L.N. Characterization of Pectobacterium carotovorum subsp. carotovorum and brasiliense from diseased potatoes in Kenya. Eur. J. Plant Pathol. 2014, 139, 557-566. [CrossRef]

6. Van der Wolf, J.; De Haan, E.; Kastelein, P.; Krijger, M.; De Haas, B.; Velvis, H.; Mendes, O.; Kooman-Gersmann, M.; Van Der Zouwen, P. Virulence of Pectobacterium carotovorum subsp. brasiliense on potato compared with that of other Pectobacterium and Dickeya species under climatic conditions prevailing in the Netherlands. Plant Pathol. 2017, 66, 571-583. [CrossRef]

7. Guerrero-Mandujano, A.; Hernández-Cortez, C.; Ibarra, J.A.; Castro-Escarpulli, G. The outer membrane vesicles: Secretion system type zero. Traffic 2017, 18, 425-432. [CrossRef]

8. Davidsson, P.R.; Kariola, T.; Niemi, O.; Palva, T. Pathogenicity of and plant immunity to soft rot pectobacteria. Front. Plant Sci. 2013, 4, 191. [CrossRef]

9. Fukuoka, S.; Kamishima, H.; Tamiya, E.; Karube, I. Spontaneous release of outer membrane vesicles by Erwinia carotovora. Microbios 1992, 72, 167-173.

10. Yaganza, E.-S.; Rioux, D.; Simard, M.; Arul, J.; Tweddell, R.J. Ultrastructural alterations of Erwinia carotovora subsp. atroseptica caused by treatment with aluminum chloride and sodium metabisulfite. Appl. Environ. Microbiol. 2004, 70, 6800-6808. [CrossRef]

11. Piotrowska, M.; Ciura, K.; Zalewska, M.; Dawid, M.; Correia, B.; Sawicka, P.; Lewczuk, B.; Kasprzyk, J.; Sola, L.; Piekoszewski, W. Capillary zone electrophoresis of bacterial extracellular vesicles: A proof of concept. J. Chromatogr. A 2020, $1621,461047$. [CrossRef] [PubMed]

12. Green, E.R.; Mecsas, J. Bacterial secretion systems: An overview. Virulence Mech. Bact. Pathog. 2016, 4, 213-239. [CrossRef]

13. Costa, T.R.; Felisberto-Rodrigues, C.; Meir, A.; Prevost, M.S.; Redzej, A.; Trokter, M.; Waksman, G. Secretion systems in Gram-negative bacteria: Structural and mechanistic insights. Nat. Rev. Microbiol. 2015, 13, 343-359. [CrossRef] [PubMed]

14. Woith, E.; Fuhrmann, G.; Melzig, M.F. Extracellular vesicles-Connecting kingdoms. Int. J. Mol. Sci. 2019, 20, 5695. [CrossRef] [PubMed]

15. Schwechheimer, C.; Kuehn, M.J. Outer-membrane vesicles from Gram-negative bacteria: Biogenesis and functions. Nat. Rev. Microbiol. 2015, 13, 605-619. [CrossRef]

16. Toyofuku, M.; Nomura, N.; Eberl, L. Types and origins of bacterial membrane vesicles. Nat. Rev. Microbiol. 2019, 17, 13-24. [CrossRef]

17. Turnbull, L.; Toyofuku, M.; Hynen, A.L.; Kurosawa, M.; Pessi, G.; Petty, N.K.; Osvath, S.R.; Cárcamo-Oyarce, G.; Gloag, E.S.; Shimoni, R. Explosive cell lysis as a mechanism for the biogenesis of bacterial membrane vesicles and biofilms. Nat. Commun. 2016, 7, 1-13. [CrossRef]

18. Roier, S.; Zingl, F.G.; Cakar, F.; Durakovic, S.; Kohl, P.; Eichmann, T.O.; Klug, L.; Gadermaier, B.; Weinzerl, K.; Prassl, R. A novel mechanism for the biogenesis of outer membrane vesicles in Gram-negative bacteria. Nat. Commun. 2016, 7, 1-13. [CrossRef]

19. Li, J.; Azam, F.; Zhang, S. Outer membrane vesicles containing signalling molecules and active hydrolytic enzymes released by a coral pathogen Vibrio shilonii AK1. Environ. Microbiol. 2016, 18, 3850-3866. [CrossRef]

20. Orench-Rivera, N.; Kuehn, M.J. Environmentally controlled bacterial vesicle-mediated export. Cell. Microbiol. 2016, 18, 1525-1536. [CrossRef]

21. Reimer, S.L.; Beniac, D.R.; Hiebert, S.L.; Booth, T.F.; Chong, P.M.; Westmacott, G.R.; Zhanel, G.G.; Bay, D.C. Comparative Analysis of Outer Membrane Vesicle Isolation Methods with an Escherichia coli tolA Mutant Reveals a Hypervesiculating Phenotype with Outer-Inner Membrane Vesicle Content. Front. Microbiol. 2021, 12, 383. [CrossRef] [PubMed]

22. Haurat, M.F.; Elhenawy, W.; Feldman, M.F. Prokaryotic membrane vesicles: New insights on biogenesis and biological roles. Biol. Chem. 2015, 396, 95-109. [CrossRef]

23. Avila-Calderón, E.D.; Araiza-Villanueva, M.G.; Cancino-Diaz, J.C.; López-Villegas, E.O.; Sriranganathan, N.; Boyle, S.M.; Contreras-Rodríguez, A. Roles of bacterial membrane vesicles. Arch. Microbiol. 2015, 197, 1-10. [CrossRef]

24. Ionescu, M.; Zaini, P.A.; Baccari, C.; Tran, S.; da Silva, A.M.; Lindow, S.E. Xylella fastidiosa outer membrane vesicles modulate plant colonization by blocking attachment to surfaces. Proc. Natl. Acad. Sci. USA 2014, 111, E3910-E3918. [CrossRef]

25. Katsir, L.; Bahar, O. Bacterial outer membrane vesicles at the plant-pathogen interface. PLoS Pathog. 2017, 13, e1006306. [CrossRef] 
26. Bahar, O.; Mordukhovich, G.; Luu, D.D.; Schwessinger, B.; Daudi, A.; Jehle, A.K.; Felix, G.; Ronald, P.C. Bacterial outer membrane vesicles induce plant immune responses. Mol. Plant-Microbe Interact. 2016, 29, 374-384. [CrossRef]

27. Kulp, A.; Kuehn, M.J. Biological functions and biogenesis of secreted bacterial outer membrane vesicles. Annu. Rev. Microbiol. 2010, 64, 163-184. [CrossRef]

28. Koeppen, K.; Hampton, T.H.; Jarek, M.; Scharfe, M.; Gerber, S.A.; Mielcarz, D.W.; Demers, E.G.; Dolben, E.L.; Hammond, J.H.; Hogan, D.A. A novel mechanism of host-pathogen interaction through sRNA in bacterial outer membrane vesicles. PLoS Pathog. 2016, 12, e1005672. [CrossRef]

29. Vanaja, S.K.; Russo, A.J.; Behl, B.; Banerjee, I.; Yankova, M.; Deshmukh, S.D.; Rathinam, V.A. Bacterial outer membrane vesicles mediate cytosolic localization of LPS and caspase-11 activation. Cell 2016, 165, 1106-1119. [CrossRef]

30. Bitto, N.J.; Chapman, R.; Pidot, S.; Costin, A.; Lo, C.; Choi, J.; D'cruze, T.; Reynolds, E.C.; Dashper, S.G.; Turnbull, L. Bacterial membrane vesicles transport their DNA cargo into host cells. Sci. Rep. 2017, 7, 1-11. [CrossRef]

31. Kuehn, M.J.; Kesty, N.C. Bacterial outer membrane vesicles and the host-pathogen interaction. Genes Dev. 2005, 19, 2645-2655. [CrossRef]

32. Jan, A.T. Outer membrane vesicles (OMVs) of gram-negative bacteria: A perspective update. Front. Microbiol. $2017,8,1053$. [CrossRef]

33. MacDonald, I.A.; Kuehn, M.J. Stress-induced outer membrane vesicle production by Pseudomonas aeruginosa. J. Bacteriol. 2013, 195, 2971-2981. [CrossRef] [PubMed]

34. Roszkowiak, J.; Jajor, P.; Guła, G.; Gubernator, J.; Żak, A.; Drulis-Kawa, Z.; Augustyniak, D. Interspecies outer membrane vesicles (OMVs) modulate the sensitivity of pathogenic bacteria and pathogenic yeasts to cationic peptides and serum complement. Int. J. Mol. Sci. 2019, 20, 5577. [CrossRef] [PubMed]

35. Horstman, A.L.; Kuehn, M.J. Enterotoxigenic Escherichia coli secretes active heat-labile enterotoxin via outer membrane vesicles. J. Biol. Chem. 2000, 275, 12489-12496. [CrossRef] [PubMed]

36. Elhenawy, W.; Debelyy, M.O.; Feldman, M.F. Preferential packing of acidic glycosidases and proteases into Bacteroides outer membrane vesicles. mBio 2014, 5, e00909-14. [CrossRef]

37. Kroniger, T.; Otto, A.; Becher, D. Proteomic analysis of bacterial (outer) membrane vesicles: Progress and clinical potential. Expert Rev. Proteom. 2018, 15, 623-626. [CrossRef]

38. Berleman, J.E.; Allen, S.; Danielewicz, M.A.; Remis, J.P.; Gorur, A.; Cunha, J.; Hadi, M.Z.; Zusman, D.R.; Northen, T.R.; Witkowska, H.E. The lethal cargo of Myxococcus xanthus outer membrane vesicles. Front. Microbiol. 2014, 5, 474. [CrossRef]

39. Marquez-Villavicencio, M.d.P.; Groves, R.L.; Charkowski, A.O. Soft rot disease severity is affected by potato physiology and Pectobacterium taxa. Plant Dis. 2011, 95, 232-241. [CrossRef]

40. Shyntum, D.Y.; Nkomo, N.P.; Shingange, N.L.; Gricia, A.R.; Bellieny-Rabelo, D.; Moleleki, L.N. The impact of type VI secretion system, bacteriocins and antibiotics on bacterial competition of Pectobacterium carotovorum subsp. brasiliense and the regulation of carbapenem biosynthesis by iron and the ferric-uptake regulator. Front. Microbiol. 2019, 10, 2379. [CrossRef]

41. Altindis, E.; Fu, Y.; Mekalanos, J.J. Proteomic analysis of Vibrio cholerae outer membrane vesicles. Proc. Natl. Acad. Sci. USA 2014, 111, E1548-E1556. [CrossRef]

42. Davies, C.; Taylor, A.J.; Elmi, A.; Winter, J.; Liaw, J.; Grabowska, A.D.; Gundogdu, O.; Wren, B.W.; Kelly, D.J.; Dorrell, N. Sodium taurocholate stimulates Campylobacter jejuni outer membrane vesicle production via down-regulation of the maintenance of lipid asymmetry pathway. Front. Cell. Infect. Microbiol. 2019, 9, 177. [CrossRef]

43. Schwanhäusser, B.; Busse, D.; Li, N.; Dittmar, G.; Schuchhardt, J.; Wolf, J.; Chen, W.; Selbach, M. Global quantification of mammalian gene expression control. Nature 2011, 473, 337-342. [CrossRef] [PubMed]

44. Consortium, G. The gene ontology resource: 20 years and still GOing strong. Nucleic Acids Res. 2019, 47, D330-D338.

45. Yu, N.Y.; Wagner, J.R.; Laird, M.R.; Melli, G.; Rey, S.; Lo, R.; Dao, P.; Sahinalp, S.C.; Ester, M.; Foster, L.J. PSORTb 3.0: Improved protein subcellular localization prediction with refined localization subcategories and predictive capabilities for all prokaryotes. Bioinformatics 2010, 26, 1608-1615. [CrossRef] [PubMed]

46. Galperin, M.Y.; Wolf, Y.I.; Makarova, K.S.; Alvarez, R.V.; Landsman, D.; Koonin, E.V. COG database update: Focus on microbial diversity, model organisms, and widespread pathogens. Nucleic Acids Res. 2021, 49, D274-D281. [CrossRef]

47. Liu, B.; Zheng, D.; Jin, Q.; Chen, L.; Yang, J. VFDB 2019: A comparative pathogenomic platform with an interactive web interface. Nucleic Acids Res. 2019, 47, D687-D692. [CrossRef]

48. Zhang, H.; Yohe, T.; Huang, L.; Entwistle, S.; Wu, P.; Yang, Z.; Busk, P.K.; Xu, Y.; Yin, Y. dbCAN2: A meta server for automated carbohydrate-active enzyme annotation. Nucleic Acids Res. 2018, 46, W95-W101. [CrossRef] [PubMed]

49. Alcock, B.P.; Raphenya, A.R.; Lau, T.T.; Tsang, K.K.; Bouchard, M.; Edalatmand, A.; Huynh, W.; Nguyen, A.-L.V.; Cheng, A.A.; Liu, S. CARD 2020: Antibiotic resistome surveillance with the comprehensive antibiotic resistance database. Nucleic Acids Res. 2020, 48, D517-D525. [CrossRef]

50. Wang, J.; Yang, B.; Leier, A.; Marquez-Lago, T.T.; Hayashida, M.; Rocker, A.; Zhang, Y.; Akutsu, T.; Chou, K.-C.; Strugnell, R.A. Bastion6: A bioinformatics approach for accurate prediction of type VI secreted effectors. Bioinformatics 2018, 34, $2546-2555$. [CrossRef]

51. Deatherage, B.L.; Lara, J.C.; Bergsbaken, T.; Barrett, S.L.R.; Lara, S.; Cookson, B.T. Biogenesis of bacterial membrane vesicles. Mol. Microbiol. 2009, 72, 1395-1407. [CrossRef] [PubMed] 
52. Schooling, S.R.; Beveridge, T.J. Membrane vesicles: An overlooked component of the matrices of biofilms. J. Bacteriol. 2006, 188, 5945-5957. [CrossRef] [PubMed]

53. Yonezawa, H.; Osaki, T.; Kurata, S.; Fukuda, M.; Kawakami, H.; Ochiai, K.; Hanawa, T.; Kamiya, S. Outer membrane vesicles of Helicobacter pylori TK1402 are involved in biofilm formation. BMC Microbiol. 2009, 9, 1-12. [CrossRef] [PubMed]

54. Seike, S.; Kobayashi, H.; Ueda, M.; Takahashi, E.; Okamoto, K.; Yamanaka, H. Outer membrane vesicles released from Aeromonas strains are involved in the biofilm formation. Front. Microbiol. 2020, 11, 613650. [CrossRef]

55. Cooke, A.C.; Florez, C.; Dunshee, E.B.; Lieber, A.D.; Terry, M.L.; Light, C.J.; Schertzer, J.W. PQS-Induced Outer Membrane Vesicles Enhance Biofilm Dispersion in Pseudomonas aeruginosa. bioRxiv 2020. [CrossRef]

56. Kubheka, G.C.; Coutinho, T.A.; Moleleki, N.; Moleleki, L.N. Colonization patterns of an mCherry-tagged Pectobacterium carotovorum subsp. brasiliense strain in potato plants. Phytopathology 2013, 103, 1268-1279. [CrossRef]

57. Moleleki, L.N.; Pretorius, R.G.; Tanui, C.K.; Mosina, G.; Theron, J. A quorum sensing-defective mutant of Pectobacterium carotovorum ssp. brasiliense 1692 is attenuated in virulence and unable to occlude xylem tissue of susceptible potato plant stems. Mol. Plant Pathol. 2017, 18, 32-44. [CrossRef]

58. Cooke, A.C.; Nello, A.V.; Ernst, R.K.; Schertzer, J.W. Analysis of Pseudomonas aeruginosa biofilm membrane vesicles supports multiple mechanisms of biogenesis. PLoS ONE 2019, 14, e0212275. [CrossRef]

59. Pérez-Cruz, C.; Delgado, L.; López-Iglesias, C.; Mercade, E. Outer-inner membrane vesicles naturally secreted by gram-negative pathogenic bacteria. PLoS ONE 2015, 10, e0116896. [CrossRef]

60. Pï, C.; Carriï, O.; Delgado, L.; Martinez, G.; Lï, C.; Mercade, E. New type of outer membrane vesicle produced by the Gramnegative bacterium Shewanella vesiculosa M7T: Implications for DNA content. Appl. Environ. Microbiol. 2013, 79, $1874-1881$.

61. Yun, S.H.; Lee, S.-Y.; Choi, C.-W.; Lee, H.; Ro, H.-J.; Jun, S.; Kwon, Y.M.; Kwon, K.K.; Kim, S.-J.; Kim, G.-H. Proteomic characterization of the outer membrane vesicle of the halophilic marine bacterium Novosphingobium pentaromativorans US6-1. J. Microbiol. 2017, 55, 56-62. [CrossRef]

62. Veith, P.D.; Chen, Y.-Y.; Gorasia, D.G.; Chen, D.; Glew, M.D.; O’Brien-Simpson, N.M.; Cecil, J.D.; Holden, J.A.; Reynolds, E.C. Porphyromonas gingivalis outer membrane vesicles exclusively contain outer membrane and periplasmic proteins and carry a cargo enriched with virulence factors. J. Proteome Res. 2014, 13, 2420-2432. [CrossRef]

63. Lee, J.; Kim, O.Y.; Gho, Y.S. Proteomic profiling of Gram-negative bacterial outer membrane vesicles: Current perspectives. Proteom.-Clin. Appl. 2016, 10, 897-909. [CrossRef]

64. Charkowski, A.; Blanco, C.; Condemine, G.; Expert, D.; Franza, T.; Hayes, C.; Hugouvieux-Cotte-Pattat, N.; Solanilla, E.L.; Low, D.; Moleleki, L. The role of secretion systems and small molecules in soft-rot Enterobacteriaceae pathogenicity. Annu. Rev. Phytopathol. 2012, 50, 425-449. [CrossRef] [PubMed]

65. Zhang, D.-F.; Li, H.; Lin, X.-M.; Peng, X.-X. Outer membrane proteomics of kanamycin-resistant Escherichia coli identified MipA as a novel antibiotic resistance-related protein. FEMS Microbiol. Lett. 2015, 362, fnv074. [CrossRef] [PubMed]

66. Hutter, C.; Lehner, R.; Wirth, C.; Condemine, G.; Peneff, C.; Schirmer, T. Structure of the oligogalacturonate-specific KdgM porin. Acta Crystallogr. Sect. D Biol. Crystallogr. 2014, 70, 1770-1778. [CrossRef] [PubMed]

67. Grinter, R.; Leung, P.M.; Wijeyewickrema, L.C.; Littler, D.; Beckham, S.; Pike, R.N.; Walker, D.; Greening, C.; Lithgow, T. Proteaseassociated import systems are widespread in Gram-negative bacteria. PLoS Genet. 2019, 15, e1008435. [CrossRef] [PubMed]

68. Chowdhury, C.; Jagannadham, M.V. Virulence factors are released in association with outer membrane vesicles of Pseudomonas syringae pv. tomato T1 during normal growth. Biochim. Biophys. Acta-Proteins Proteom. 2013, 1834, 231-239. [CrossRef]

69. Solé, M.; Scheibner, F.; Hoffmeister, A.-K.; Hartmann, N.; Hause, G.; Rother, A.; Jordan, M.; Lautier, M.; Arlat, M.; Büttner, D. Xanthomonas campestris pv. vesicatoria secretes proteases and xylanases via the Xps type II secretion system and outer membrane vesicles. J. Bacteriol. 2015, 197, 2879-2893. [CrossRef]

70. Nascimento, R.; Gouran, H.; Chakraborty, S.; Gillespie, H.W.; Almeida-Souza, H.O.; Tu, A.; Rao, B.J.; Feldstein, P.A.; Bruening, G.; Goulart, L.R. The type II secreted lipase/esterase LesA is a key virulence factor required for Xylella fastidiosa pathogenesis in grapevines. Sci. Rep. 2016, 6, 18598.

71. McMillan, H.M.; Zebell, S.G.; Ristaino, J.B.; Dong, X.; Kuehn, M.J. Protective plant immune responses are elicited by bacterial outer membrane vesicles. Cell Rep. 2021, 34, 108645. [CrossRef] [PubMed]

72. Corbett, M.; Virtue, S.; Bell, K.; Birch, P.; Burr, T.; Hyman, L.; Lilley, K.; Poock, S.; Toth, I.; Salmond, G. Identification of a new quorum-sensing-controlled virulence factor in Erwinia carotovora subsp. atroseptica secreted via the type II targeting pathway. Mol. Plant-Microbe Interact. 2005, 18, 334-342. [CrossRef] [PubMed]

73. Kazemi-Pour, N.; Condemine, G.; Hugouvieux-Cotte-Pattat, N. The secretome of the plant pathogenic bacterium Erwinia chrysanthemi. Proteomics 2004, 4, 3177-3186. [CrossRef] [PubMed]

74. Franza, T.; Expert, D. Iron uptake in soft rot Erwinia. In Iron Uptake and Homeostasis in Microorganisms; Cornelis, P., Andrews, S.C., Eds.; Caister Academic Press: Poole, UK, 2010; pp. 101-115.

75. Aoki, S.K.; Diner, E.J.; de Roodenbeke, C.T.K.; Burgess, B.R.; Poole, S.J.; Braaten, B.A.; Jones, A.M.; Webb, J.S.; Hayes, C.S.; Cotter, P.A. A widespread family of polymorphic contact-dependent toxin delivery systems in bacteria. Nature 2010, 468, 439-442. [CrossRef]

76. Charkowski, A.O. Biology and control of Pectobacterium in potato. Am. J. Potato Res. 2015, 92, 223-229. [CrossRef]

77. Chattopadhyay, M.K.; Jagannadham, M.V. Vesicles-mediated resistance to antibiotics in bacteria. Front. Microbiol. 2015, 6, 758. [CrossRef] [PubMed] 